\title{
Retraction
}

\section{Retracted: Microbial Ecology of Anaerobic Digesters: The Key Players of Anaerobiosis}

\author{
The Scientific World Journal \\ Received 11 June 2017; Accepted 11 June 2017; Published 12 July 2017 \\ Copyright (C) 2017 The Scientific World Journal. This is an open access article distributed under the Creative Commons Attribution \\ License, which permits unrestricted use, distribution, and reproduction in any medium, provided the original work is properly \\ cited.
}

The Scientific World Journal has retracted the article titled "Microbial Ecology of Anaerobic Digesters: The Key Players of Anaerobiosis" [1]. The article was found to contain a substantial amount of material from the following published articles and others:

(i) Krzysztof Ziemiński and Magdalena Frąc, Methane fermentation process as anaerobic digestion of biomass: Transformations, stages and microorganisms, African Journal of Biotechnology, Vol. 11, No. 18. (March 2012), pp. 4127-4139, doi: 10.5897/AJBX11.054 https://www.ajol.info/index.php/ajb/article/view/101067

(ii) José L. Sanz, Thorsten Köchling, Molecular biology techniques used in wastewater treatment: An overview, Process Biochemistry, Volume 42, Issue 2, February 2007, Pages 119-133, ISSN 1359-5113, https://dx.doi.org/ 10.1016/j.procbio.2006.10.003. (http://www.sciencedirect.com/science/article/pii/S1359511306003989)

(iii) Jo De Vrieze, Tom Hennebel, Nico Boon, Willy Verstraete, Methanosarcina: The rediscovered methanogen for heavy duty biomethanation, Bioresource Technology, Volume 112, May 2012, Pages 1-9, ISSN 09608524, https://dx.doi.org/10.1016/j.biortech.2012.02.079. (http://www.sciencedirect.com/science/article/pii/ S0960852412003306)

(iv) Paul J. Weimer, James B. Russell, Richard E. Muck, Lessons from the cow: What the ruminant animal can teach us about consolidated bioprocessing of cellulosic biomass, Bioresource Technology, Volume 100, Issue 21, November 2009, Pages 5323-5331, ISSN 0960-8524, https://dx.doi.org/10.1016/j.biortech .2009.04.075. (http://www.sciencedirect.com/science/ article/pii/S0960852409006476)

(v) Azam Jeihanipour, Claes Niklasson, Mohammad J. Taherzadeh, Enhancement of solubilization rate of cellulose in anaerobic digestion and its drawbacks, Process Biochemistry, Volume 46, Issue 7, July 2011, Pages 1509-1514, ISSN 1359-5113, https://dx.doi.org/ 10.1016/j.procbio.2011.04.003. (http://www.sciencedirect.com/science/article/pii/S1359511311001334), without citation.

\section{References}

[1] F. Ali Shah, Q. Mahmood, M. M. Shah, A. Pervez, and S. A. Asad, "Microbial ecology of anaerobic digesters: the key players of anaerobiosis," The Scientific World Journal, vol. 2014, Article ID 183752, 21 pages, 2014 


\title{
Review Article
}

\section{Microbial Ecology of Anaerobic Digesters: The Key Players of Anaerobiosis}

\author{
Fayyaz Ali Shah, Qaisar Mahmood, Mohammad Maroof Shah, \\ Arshid Pervez, and Saeed Ahmad Asad
}

Department of Environmental Sciences, COMSATS Institute of Information Technology, Abbottabad 22060, Pakistan

Correspondence should be addressed to Qaisar Mahmood; mahmoodzju@gmail.com

Received 4 August 2013; Accepted 10 December 2013; Published 19 February 2014

Academic Editors: C. Cameselle and G. Sen

Copyright (C) 2014 Fayyaz Ali Shah et al. This is an open access article distributed under the Creative Commons Attribution License, which permits unrestricted use, distribution, and reproduction in any medium, provided the original work is properly cited.

\begin{abstract}
Anaerobic digestion is the method of wastes treatment aimed at a reduction of their hazardous effects on the biosphere. The mutualistic behavior of various anaerobic microorganisms results in the decomposition of complex organic substances into simple, chemically stabilized compounds, mainly methane and $\mathrm{CO}_{2}$. The conversions of complex organic compounds to $\mathrm{CH}_{4}$ and $\mathrm{CO}_{2}$ are possible due to the cooperation of four different groups of microorganisms, that is, fermentative, syntrophic, acetogenic, and methanogenic bacteria. Microbes adopt various pathways to evade from the unfavorable conditions in the anaerobic digester like competition between sulfate reducing bacteria (SRB) and methane forming bacteria for the same substrate. Methanosarcina are able to use both acetoclastic and hydrogenotrophic pathways for methane production. This review highlights the cellulosic microorganisms, structure of cellulose, inoculum to substrate ratio, and source of inoculum and its effect on methanogenesis. The molecular techniques such as DGGE (denaturing gradient gel electrophoresis) utilized for dynamic changes in microbial communities and FISH (fluorescent in situ hybridization) that deal with taxonomy and interaction and distribution of tropic groups used are also discussed.
\end{abstract}

\section{Introduction}

Methanogenesis is complex, redox biochemical reactions occurring under anaerobic conditions. Under symbiotic effects of various anaerobic and relatively anaerobic bacteria, multimolecular organic substances are decomposed into simple, chemically stabilized compounds-methane and carbon dioxide [1]. Generally, this process consists of liquefaction and hydrolysis of insoluble compounds and gasification of intermediates. This is accompanied by a partial or complete mineralization and humification of organic substance [2]. An advantage of the process of anaerobic digestion is the production of biogas, a high energy fuel which may be used to produce environmental-friendly energy. It is basically for this reason that scientists and power industry companies have been interested in anaerobic digestion for almost 140 years. Biotechnology of biogas production usually refers to digestion of various types of organic wastes, food industry wastewater, sewage sludge, animal excrements or organic fraction of municipal wastes, and so forth. In some countries, subjected to anaerobic digestion are plants deliberately grown for this purpose, for example, maize $[3,4]$. Currently in many European countries, the production of biomass as a substrate for the biogas plants is well established. In the most extreme European case, the German government has adopted measures in 2011 to reduce even monoculture maize production for energy purposes $[5,6]$.

Digestion connected with biogas production may play a triple part. First, it is a method of converting the energy contained in biomass into a useful fuel (biogas) which may be stored and transported. Second, it is a method of recycling of organic wastes into stable soil additives, that is, valuable liquid fertilizer and energy. Third, it is a method of wastes treatment aimed at a reduction of their hazardous effects on the environment [7].

Biogas is a digester gas arising from the activity of a consortium of anaerobic bacteria which decompose organic matter. Its composition depends on the type of raw material subjected to the digestion process and on the method of conducting this process and is as follows. Methane $\mathrm{CH}_{4}$ 
(50-75\%), carbon dioxide $\mathrm{CO}_{2}$ (25-45\%), hydrogen sulfide $\mathrm{H}_{2} \mathrm{~S}(0-1 \%)$, hydrogen $\mathrm{H}_{2}(0-1 \%)$, carbon monoxide $\mathrm{CO}(0-$ $2 \%)$, nitrogen $\mathrm{N}_{2}(0-2 \%)$, ammonia $\mathrm{NH}_{3}(0-1 \%)$, oxygen $\mathrm{O}_{2}$ $(0-2 \%)$, and water $\mathrm{H}_{2} \mathrm{O}(2-7 \%)$ [5]. The biogas obtained may be used in various fields of economy [8,9], mainly in technological processes and for power engineering purposes including the following.

(1) Production of thermal energy in gas boilers and production of thermal and electrical energy in associated units (from $1 \mathrm{~m}^{3}$ of biogas in associated production of energy, $2.1 \mathrm{kWh}$ of electrical energy and $2.9 \mathrm{kWh}$ of heat are obtained);

(2) production of electrical energy in spark-ignition or turbine engines;

(3) using the obtained gas as a fuel in motor-car engines;

(4) use in various technological processes, for example, in the production of methanol.

The average efficiency of methanogenesis reaches approximately $0.24 \mathrm{~m}^{3}$ of methane from $1 \mathrm{~kg}$ of dry organic matter. One $\mathrm{m}^{3}$ of biogas having calorific value of $26 \mathrm{MJ} \mathrm{m}^{-3}$ may replace $0.77 \mathrm{~m}^{3}$ of natural gas with $33.5 \mathrm{MJ}$ calorific value, $1.1 \mathrm{~kg}$ of hard coal with $23.4 \mathrm{MJ}$ calorific value, or $2 \mathrm{~kg}$ of firewood of 13.3 MJ calorific value [10].

\section{Stages of Anaerobic Degradation of Organic Wastes}

Microbiology of anaerobic transformation of organic wastes is a process which involves many different bacterial species, such as hydrolytic, acid forming, acetogenic, and methanogenic bacteria which produce $\mathrm{CO}_{2}$ and $\mathrm{CH}_{4}$ as the main products of the digestion process $[11,12]$. A specific characteristic of methane digestion is its phasing. Each of them accounts for degradation of a different type of compounds.

2.1. Hydrolysis. During hydrolysis of the polymerized, mostly insoluble organic compounds, like carbohydrates and proteins, fats are decomposed into soluble monomers and dimers, that is, monosaccharides, amino acids, and fatty acids. This stage of the methanogenesis passes through extracellular enzymes from the group of hydrolases (amylases, proteases, and lipases) produced by appropriate strains of hydrolytic bacteria. Hydrolysis of hardly decomposable polymers, that is, cellulose and cellulo-cottons is considered to be a stage which limits the rate of wastes digestion. During solid wastes digestion, only $50 \%$ of organic compounds undergo biodegradation. The remaining part of the compounds remains in their primary state because of the lack of enzymes participating in their degradation $[13,14]$.

The rate of hydrolysis process depends on parameters such as size of particles, $\mathrm{pH}$, production of enzymes, diffusion, and adsorption of enzymes on the particles of wastes subjected to the digestion process. Hydrolysis is carried out by bacteria from the group of relative anaerobes of genera like Streptococcus and Enterobacterium $[15,16]$.
2.2. Acidogenesis (Acidification Phase). During this stage, the acidifying bacteria convert water-soluble chemical substances, including hydrolysis products, to short-chain organic acids (formic, acetic, propionic, butyric, and pentanoic), alcohols (methanol, ethanol), aldehydes, carbon dioxide, and hydrogen. From decomposition of proteins, amino acids and peptides arise, which may be a source of energy for anaerobic microorganisms. Acidogenesis may be two-directional due to the effects of various populations of microorganisms. This process may be divided into two types: hydrogenation and dehydrogenation. The basic pathway of transformations passes through acetates, $\mathrm{CO}_{2}$, and $\mathrm{H}_{2}$, whereas other acidogenesis products play an insignificant role. As a result of these transformations, methanogens may directly use the new products as substrates and energy source. Accumulation of electrons by compounds such as lactate, ethanol, propionate, butyrate, and higher volatile fatty acids is the bacterial response to an increase in hydrogen concentration in the solution. The new products may not be used directly by methanogenic bacteria and must be converted by obligatory bacteria producing hydrogen in the process called acetogenesis. Among the products of acidogenesis, ammonia and hydrogen sulfide which give an intense unpleasant smell to this phase of the process should also be mentioned $[8,13,17]$. The acid phase bacteria belonging to facultative anaerobes use oxygen accidentally introduced into the process, creating favorable conditions for the development of obligatory anaerobes of the following genera: Pseudomonas, Bacillus, Clostridium, Micrococcus, or Flavobacterium.

2.3. Acetogenesis. In this process, the acetate bacteria including those of the genera of Syntrophomonas and Syntrophobacter convert the acid phase products into acetates and hydrogen which may be used by methanogenic bacteria [18]. Bacteria like Methanobacterium suboxydans account for decomposition of pentanoic acid to propionic acid, whereas Methanobacterium propionicum accounts for decomposition of propionic acid to acetic acid. As a result of acetogenesis, hydrogen is released, which exhibits toxic effects on the microorganisms which carry out this process. Therefore, a symbiosis is necessary for acetogenic bacteria with autotrophic methane bacteria using hydrogen, hereinafter referred to as syntrophy $[9,18]$. Acetogenesis is a phase which depicts the efficiency of biogas production, because approximately $70 \%$ of methane arises in the process of acetates reduction. Consequently, acetates are a key intermediate product of the process of methane digestion. In acetogenesis phase, approximately $25 \%$ of acetates are formed and approximately $11 \%$ of hydrogen is produced in the wastes degradation process [18].

2.4. Methanogenesis. This phase consists in the production of methane by methanogenic bacteria. Methane in this phase of the process is produced from substrates which are the products of previous phases, that is, acetic acid, $\mathrm{H}_{2}, \mathrm{CO}_{2}$, and formate and methanol, methylamine, or dimethyl sulfide. Despite the fact that only few bacteria are able to produce methane from acetic acid, a vast majority of $\mathrm{CH}_{4}$ arising in 
TABLE 1: Microbial cooperation in organic matter degradation [7].

\begin{tabular}{lcccc}
\hline Microorganisms & Electron donor & Electron acceptor & Product & Reaction type \\
\hline Fermentative bacteria & Organic carbon & Organic carbon & $\mathrm{CO}_{2}$ & Fermentation \\
Syntrophic bacteria & Organic carbon & Organic carbon & $\mathrm{H}_{2}$ & Acidogenesis \\
Acetogenic bacteria & Organic carbon $/ \mathrm{H}_{2}$ & $\mathrm{CO}_{2}$ & $\mathrm{CH}_{3} \mathrm{COOH}$ & Acetogenesis \\
Methogenic bacteria & Organic carbon $/ \mathrm{H}_{2}$ & $\mathrm{CO}_{2}$ & $\mathrm{CH}_{4}$ & Methanogenesis \\
\hline
\end{tabular}

the methane digestion process results from acetic acid conversions by heterotrophic methane bacteria [19]. Only $30 \%$ of methane produced in this process comes from $\mathrm{CO}_{2}$ reduction carried out by autotrophic methane bacteria. During this process. $\mathrm{H}_{2}$ is used up, which creates good conditions for the development of acid bacteria which give rise to short-chain organic acids in acidification phase and consequently to too low production of $\mathrm{H}_{2}$ in acetogenic phase. A consequence of such conversions may be gas rich in $\mathrm{CO}_{2}$, because only its insignificant part will be converted into methane $[20,21]$

\section{Cooperation of Microorganisms of Methane Fermentation Process}

Conversions of complex organic compounds to $\mathrm{CH}_{4}$ and $\mathrm{CO}_{2}$ are possible owing to the cooperation of four different groups of microorganisms and are presented in Table 1. These microorganisms may be counted among primary fermentation bacteria, secondary fermentation bacteria (syntrophic and acetogenic bacteria), and two types of methanogens belonging to domain Archaea. These microorganisms occur in natural environment and fulfill various roles during the process of anaerobic degradation of wastes [13]. Syntrophy is a form of symbiosis of two metabolically different groups of bacteria, which enables degradation of various substrates $[9,11]$.

Cooperation of the population of microorganisms enables synthesis of certain products which are then used by another group of bacteria. The bacteria belonging to domain Archaea, which are involved in the production of methane, exhibit synergistic relationships with other populations of microorganisms. They may develop only when hydrogen is used by hydrogenotrophs. Such cooperation between microorganisms producing hydrogen and using hydrogen was defined as interspecific transfer of hydrogen [13]. Syntrophy between microorganisms producing and using hydrogen allows for the growth and activity of these microorganisms.

The phenomenon of interspecific transfer of hydrogen enables the growth of the so-called syntrophic bacteria (Syntrophomonas, Syntrophospora, and Syntrophobacter) which oxidise such compounds as propionate and butyrate and thereby obligatorily use hydrogen as electron acceptor. The reaction of butyrate oxidation, carried out by these microorganisms, may occur only when low pressure of $\mathrm{H}_{2}$ is maintained $[11,22]$. Syntrophic bacteria cannot grow in the form of pure cultures but only when accompanied by microorganisms using hydrogen produced by them, for example, mutanogenic archeons. So syntrophy is a process in which the compound's decomposition occurs, with participation of two or more microorganisms and none of them can use this compound separately. Syntrophic bacteria produce adenosine triphosphate (ATP) as a result of substrate phosphorylation or oxidation used in their metabolism of not only fatty acids but also alcohols produced by other microorganisms as a result of digestion. These compounds are converted to acetate and hydrogen which are used by methanogenic archeons [9]. Bacteria of Syntrophomonas genus oxidise butyric acid and caproic acid to $\mathrm{CH}_{3} \mathrm{COOH}$ and $\mathrm{H}_{2}$. Species belonging to this genus oxidise also pentanoic and enanthic acids to $\mathrm{CH}_{3} \mathrm{COOH}, \mathrm{CO}_{2}$, and $\mathrm{H}_{2}$. Oxidation of propionate is also an important stage of methanogenesis process in which syntrophic consortia of acetogenic bacteria and methanogenic archeons obligatorily participated [11]. Most of the propionate-oxidising syntrophic bacteria, so far isolated from different environments, belonged to Syntrophobacter genus from $\delta$-proteobacteria group. $\mathrm{CH}_{3} \mathrm{COOH}$ and $\mathrm{H}_{2}$ produced by the mentioned bacteria are used by methanogenic archeons to produce methane [12]. Species of Syntrophobacter genus are able to use sulfates as electron acceptor in the process of propionate oxidation. Syntrophic oxidation of propionate is not limited to gram-negative bacteria but also to gram-positive bacteria in which a similar phenomenon was observed. Two thermophilic, gram-positive species of syntrophic bacteria oxidising propionate have been described as follows: Desulfotomaculum thermobenzoicum subsp. thermosyntrophicum and Desulfovibrio [9]. Desulfotomaculum, similarly to Syntrophobacter may use sulfates as electron acceptors. Desulfovibrio may participate, along with Methanobacterium genus, in forming $\mathrm{CH}_{3} \mathrm{COOH}$ and $\mathrm{H}_{2}$ in the process of anaerobic respiration and digestion, using sulfate and lactate to make these products. The Desulphovibrio compete with methane forming bacteria by using the same substrate and produce $\mathrm{H}_{2} \mathrm{~S}$ and hinder the methane formation as shown in Figure 1.

3.1. Substrate to Inoculum Ratio. Inoculum to substrate ratio (ISR) has been shown to affect the methane yield, methane production rate, and the consumption of VFAs. ISR is generally presented on VS basis. ISR affects the occurrence and duration of lag phase (extracellular hydrolysis), methanogenesis, VS/COD reduction, and susceptibility of the microorganisms of the inhibitory effects $[23,24]$. For a stable process, the ISR is a major parameter affecting the process of anaerobic digestion and should be higher than 1 in terms of VS. References $[25,26]$ have reported changes in the hydrolysis time of cellulose with changing the inoculums concentration. The optimum inoculum to substrate ratio depends on the source of inoculum. The different sources of inoculums will have 


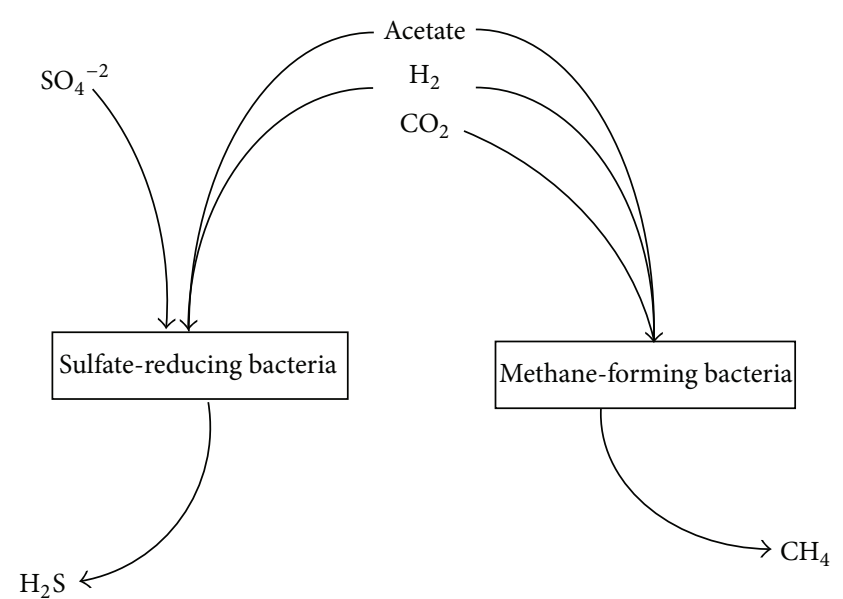

FIGURE 1: Many different groups of bacteria within the anaerobic digester often compete for the same substrate and electron acceptor. Methane is produced by methane-forming bacteria and a variety of acids and alcohols are produced by sulfate reducing bacteria. Hydrogen is used with sulfate $\left(\mathrm{SO}_{4}{ }^{-2}\right)$ by sulfate-reducing bacteria and hydrogen sulfide $\left(\mathrm{H}_{2} \mathrm{~S}\right)$ is produced. [41].

different metabolic activities so the optimum ratio required for optimum anaerobic digestion of a particular feed may vary using inoculums from different sources. An optimum ISR ensures the presence of the groups of microorganisms required for the complete anaerobic digestion [27]. Lower ratio of inoculums to feed can lead to accumulation of VFAs and result in inhibition of methanogenesis $[23,28]$. ISR is one of the crucial parameters but unfortunately is not included in the experimental design by many researchers [29]. The ISR can affect the methane production rate or methane yield. The kinetics of methane production were dependent on the concentration of inoculums used; however, the final yield was the same [30].

The amount of inoculum used per tonne of waste for starting the anaerobic process was shown to have a relevant effect on both biogas and biomethane production. For a waste-toinoculum ratio ranging from $1: 1$ to $1: 3(\mathrm{w} / \mathrm{w})$, the energy production increased from about $100 \mathrm{kWh} /$ tonne to about $380 \mathrm{kWh} /$ tonne of waste organic fraction. Consequently, the investment costs also rise, going from about $180 €$ to more than $370 € /$ tonne of treated municipal solid waste organic fraction. The economic optimization analysis showed that the waste-to-inoculum ratio that minimized the treatment cost ranged from $1: 1.5$ to $1: 2.5$, being strongly influenced by the plant size (i.e., electrical efficiency) and by the Green Certificate value. Considering the cost of producing electrical energy, the optimum ratio was $1: 2$, leading to a cost of $0.26 € / \mathrm{kWh}$, during the investment period, and of $0.14 € / \mathrm{kWh}$, after the investment period [31].

Inoculation will not be of much use for the fermentation of easily biodegradable waste. For initiating methanogenesis of such wastes, it is strongly recommended not to homogenize inoculums and waste, which will dissipate and degrade the active methanogens. Multiple loading of the waste to the inoculum is superior to single shot loading if the total organic loading rate is the same. It is suggested that an appropriate inoculation method could initiate methanogenesis rapidly even at a low inoculation rate [32].

Within days of incubation of MSW at $55^{\circ} \mathrm{C}$, methane was produced at a high rate. In an attempt to narrow down which components of typical MSW contained the thermophilic methanogens, vacuum cleaner dust, banana peel, kitchen waste, and garden waste were tested as inoculum for thermophilic methanogenesis with acetate as the substrate. Results singled out grass turf as the key source of thermophilic acetate degrading methanogenic consortia. Within 4 days of anaerobic incubation $\left(55^{\circ} \mathrm{C}\right)$, anaerobically incubated grass turf samples produced methane accompanied by acetate degradation enabling successful start-up of thermophilic anaerobic digestion. Stirring of the culture was not conducive for successful start-up as it resulted specifically in propionate accumulation [33].

\section{Methanogens-Key Microorganisms of the Methane Fermentation Process}

Methanogens as absolutely anaerobic microorganisms inhabit anaerobic environment ecosystems, such as tundras, marshlands, rice fields, bottom deposit, swamps, sandy lagoons, tanks where wastewater is decomposed, sewage sludge, solid wastes landfills, and ruminants' stomach $[15,16,34]$. These microorganisms are particularly sensitive to changes in temperature and $\mathrm{pH}$, their development being inhibited by a high level of volatile fatty acids and other compounds, that is, hydrogen, ammonia, and sulphur hydrogen in the environment [34].

Among methanogenic microorganisms, we can distinguish psychro-, meso- and thermophilic microorganisms. Mesophilic and thermophilic bacteria described in literature exhibit high activity within temperatures, respectively, 28 to $42^{\circ} \mathrm{C}$ and 55 to $72^{\circ} \mathrm{C}$. So far, no anaerobic psychrophilic bacterium has been found which would exhibit activity at a temperature lower than $25^{\circ} \mathrm{C}$. Temperature is very important for methanogenic bacteria, due to a limited temperature resistance of their enzymatic structures.

Methanogenic bacteria usually develop in inert conditions, with environmental $\mathrm{pH}$ from 6.8 to 7.2. This, however, does not mean that methanogenesis does not occur in environments of acid or alkaline reaction. Methanogens which decompose acetates (Methanosarcina barkeri and Methanosarcina sp.) were isolated from environments of approximately $\mathrm{pH} 5$, while methylotrophic and hydrogen-oxidising methanogens were found in strongly alkaline ecosystems [16]. Methanogenic bacteria belong to chemolithotrophs, because they are capable to use $\mathrm{CO}_{2}$ as a source of carbon $[16,34]$.

Methanogens are an important group of microorganisms for several reasons, the most important being their ability to process organic matter to methane. Methanogenic bacteria are used in anaerobic decomposition of wastewater, as a part of the wastes treatment system. Sedimentation processes are also used in stabilization of primary and secondary sludge arising in the process of aerobic wastewater treatment. These microorganisms arouse also some interest in pharmaceutical 
TABLE 2: Kinetics characteristics of various methanogens.

\begin{tabular}{lccc}
\hline Parameter & Methanosaeta & Methanosarcina & Reference \\
\hline$U_{\text {max }}\left(\mathrm{d}^{-1}\right)$ & 0.20 & 0.60 & {$[50,52,58]$} \\
$K_{S}\left(\mathrm{mg} \mathrm{COD} \mathrm{L}^{-1}\right)$ & $10-50$ & $200-280$ & $<7000$ \\
$\mathrm{NH}_{4}^{+}\left(\mathrm{mg} \mathrm{L}^{-1}\right)$ & $<3000$ & $<18,0000$ & {$[50,52,58,59]$} \\
$\mathrm{Na}^{+}\left(\mathrm{mg} \mathrm{L}^{-1}\right)$ & $<10,000$ & $5-8$ & {$[[56,57,61]$} \\
$\mathrm{pH}$ range & $6.5-8.5$ & $<0.8-1$ & {$[65]$} \\
$\mathrm{pH}$ shock & $<0.5$ & $1-70$ & {$[64,66,158,159]$} \\
Temperature range $\left({ }^{\circ} \mathrm{C}\right)$ & $7-6.5$ & $<15000$ & {$[64]$} \\
Acetate concentration $\left(\mathrm{mg} \mathrm{L}^{-1}\right)$ & $<3000$ & & {$[44,160,161]$} \\
\hline
\end{tabular}

TABLE 3: Typical reactions carried out by methanogens during anaerobic process [11].

\begin{tabular}{lr}
\hline & Reaction carried out by methanogens \\
\hline Hydrogen: & $4 \mathrm{H}_{2}+\mathrm{CO}_{2} \rightarrow \mathrm{CH}_{4}+2 \mathrm{H}_{2} \mathrm{O}$ \\
Acetate: & $\mathrm{CH}_{3} \mathrm{COOH} \rightarrow \mathrm{CH}_{4}+\mathrm{CO}_{2}$ \\
Formate: & $4 \mathrm{HCOH} \rightarrow \mathrm{CH}_{4}+\mathrm{CO}_{2}+2 \mathrm{H}_{2} \mathrm{O}$ \\
Methanol & $4 \mathrm{CH}_{3} \mathrm{OH}_{3} \rightarrow 3 \mathrm{CH}_{4}+\mathrm{CO}_{2}+2 \mathrm{H}_{2} \mathrm{O}$ \\
Carbon monoxide: & $4 \mathrm{CO}+2 \mathrm{H}_{2} \mathrm{O} \rightarrow \mathrm{CH}_{4}+3 \mathrm{H}_{2} \mathrm{CO}_{3}$ \\
Trimethylamine: & $4\left(\mathrm{CH}_{3}\right) 3 \mathrm{~N}^{2} 6 \mathrm{H}_{2} \mathrm{O} \rightarrow 9 \mathrm{CH}_{4}+3 \mathrm{CO}_{2}+4 \mathrm{NH}_{3}$ \\
Dimethylamine: & $2\left(\mathrm{CH}_{3}\right) 2 \mathrm{NH}_{2} 2 \mathrm{H}_{2} \mathrm{O} \rightarrow 3 \mathrm{CH}_{4}+\mathrm{CO}_{2}+2 \mathrm{NH}_{3}$ \\
Methylamine: & $4\left(\mathrm{CH}_{3}\right) \mathrm{NH}_{2}+2 \mathrm{H}_{2} \mathrm{O} \rightarrow 3 \mathrm{CH}_{4}+\mathrm{CO}_{2}+4 \mathrm{NH}_{3}$ \\
Methyl mercaptans: & $2\left(\mathrm{CH}_{3}\right)_{2} \mathrm{~S}_{3}+3 \mathrm{H}_{2} \mathrm{O} \rightarrow 3 \mathrm{CH}_{4}+\mathrm{CO}_{2}+\mathrm{H}_{2} \mathrm{~S}$ \\
Metals: & $4 \mathrm{MeO}^{+}+8 \mathrm{H}^{+}+\mathrm{CO}_{2} \rightarrow 4 \mathrm{Me}^{++}+\mathrm{CH}_{4}+2 \mathrm{H}_{2} \mathrm{O}$ \\
\hline
\end{tabular}

industry, because they may constitute a source of vitamin B12 [35].

4.1. Taxonomy and Morphology of Methanogens. All alive organisms, based on analysis and comparison of conservative phylogenetic features, through analysis of $16 \mathrm{~S}$ and $18 \mathrm{~S}$ rRNA, were classified to three main taxonomic units of the living world. Three phylogenetic domains may be distinguished: Archaea, Bacteria and Eukarya. According to analysis of sequence $16 \mathrm{~S}$ rRNA, [7] 4133 methanogenic bacteria were classified to domain Archaea. Among the microorganisms within domain Archaea, four groups are distinguished, the most visible being Crenarchaeota and Euryarchaeota. In taxonomic and phenotypic respect, methanogens belong to Euryarchaeota group [36]. Methanogenic bacteria are divided into 4 classes, 5 orders, 9 families, and 26 genera [11]. As mentioned earlier, according to assumed classification of live organisms, methanogens are archeons. Unlike bacteria, methanogens do not have a typical peptidoglycan (murein) skeleton and are characterized by different metabolism. Besides, methanogens' cytoplasmatic membrane consists of lipids composed of isoprenoid hydrocarbons glycerol lipids. Methanogene ribosomes exhibit a size similar to that of eubacteria ribosome, but the sequence of principles in ribosome RNA, especially $16 \mathrm{~S}$ rRNA, is completely different [37]. Methanogens are largely differentiated morphologically. Methanogens exhibit almost all shapes occurring in bacteria: cocci (Methanococcus), rods (Methanobacterium), short rods (Methanobrevibacter), Spirillaceae (Methanospirillum), sarcina (Methanosarcina), and filiforms (Methanothrix). The size of these microorganisms ranges from 0.3 to $7.4 \mu \mathrm{m}$ [21]. The properties of selected methanogens are presented in Table 2. Typical reactions carried out by methanogens during anaerobic processes are shown in Table 3.

4.2. Substrates Used by Methanogenic Bacteria. Methanogens process a limited quantity of simple organic substrates, the most important of which are $\mathrm{CH}_{3} \mathrm{COOH}, \mathrm{H}_{2}$, and $\mathrm{CO}_{2}$ [13]. Most methanogenic bacteria are able to use $\mathrm{H}_{2}$ and $\mathrm{CO}_{2}$ for their growth (Table 3), although certain species process $\mathrm{CH}_{3} \mathrm{COOH}, \mathrm{CH}_{3} \mathrm{NH}_{2}$, and $\mathrm{HCOOH}$ [8]. Owing to used substrates, methanogens are divided into two groups [11].

4.2.1. Hydrogenotrophic. This group of microbe uses only $\mathrm{H}_{2}$ and $\mathrm{CO}_{2}$. Partial pressure of hydrogen is an important parameter which defines stability and disturbances in the anaerobic digestion process. Therefore, the activity of hydrotrophic methanogens is essential for stability and efficiency of the digestion process. Efficiency and activity of hydrogenotrophic methanogens are important in both anaerobic processing of simple, soluble types of substrates (such as acetate, ethanol, dextrose, and propionate) and various types of wastes (e.g., oil).

4.2.2. Acetotrophic. It reduces methyl groups, such as species of Methanosarcinales genus which use simple compounds for their growth, that is, acetate. Acetate is one of the most 
important substrates for methanogenic bacteria, because over $70 \%$ of biomethane comes from processing of acetic acid. Acetotrophic methanogens are obligatory anaerobes which process acetate to methane and carbon dioxide. The activity and efficiency of this group of microorganisms are ic processing of biomass of complex organic compounds [38]. Methanogenic bacteria binding hydrogen were found to belong to family Methanobacteriaceae [3].

Manure is a complex type of substrate composed of hydrocarbons, proteins, and acids. Characteristics of the population of bacteria and archaeans in anaerobic thermophilic processing of manure indicated a dominance of two species: Methanoculleus thermophilicus (hydrogenotrophic) and Methanosarcina thermophila (acetotrophic). The main hydrogenotrophic microorganisms participating in anaerobic processing of fruit and vegetable wastes comprise Methanosphaera stadtmanae and Methanobrevibacterwolinii [39].

Counted among acetotrophic methanogens should be the species belonging to genus Methanosarcina. It was found out that during anaerobic processing of sewage sludge and manure, the number of microorganisms of Methanosaeta genus decreased with increasing acetate in the environment, with simultaneous intensive growth of the bacteria belonging to Methanosarcina genus which are acetotrophic methanogens [20]. The studies on the dynamics of the population of anaerobic microorganisms participating in degradation of municipal wastes and sewage sludge indicated that Methanosaeta concilii was a dominant species among acetotrophic methanogens [22].

The rate of the development of digestive bacteria depends on the type of applied substrate. If the substrates are carbohydrates, the rate of bacteria generation in acid phase amounts to $5 \mathrm{~h}$; whereas in the case when fats are the substrate, the time is prolonged to approximately $72 \mathrm{~h}$. The generation time, in acetogenesis phase, for bacteria using propionic and fatty acids reaches, 84 and $131 \mathrm{~h}$, respectively. In the methanogenesis phase, the generation time ranges between 15 and $85 \mathrm{~h}[40]$.

\subsubsection{Methanosarcina: The All Rounder Microbe for Anaerobic} Digestion. The methanogenic Archaea are responsible for the final and critical step of anaerobic digestion, as they produce valuable methane. One of the major drawbacks of anaerobic digestion is however the sensitivity of the methanogenic consortium to different environmental factors. An abrupt change in $\mathrm{pH}$, an increase in salt or organic matter concentration, an alteration of the loading rate, or the introduction of a toxic compound often causes system failure [47-49]. Overloading is a frequent problem in anaerobic digestion since it leads to accumulation of fatty acids, as these are no longer efficiently removed by the methanogens. This is because of their low growth rates, compared to the acidogenic and acetogenic bacteria, which cause the uncoupling of the acetogenic bacteria and the methanogens [50]. Overloading thus causes an accumulation of fatty acids to concentrations which may have a toxic effect on the methanogens [48]. It also lowers the $\mathrm{pH}$ to suboptimal values, since the optimal $\mathrm{pH}$ range for methanogens lies between 6.8 and $7.5[50,51]$. Taking these aspects into account, anaerobic digestion in continuously stirred tank reactors (CSTR) commonly operates at organic loading rates (OLR) below their optimum capacity to avoid overloading and sludge retention times (SRT) in the order of 20 days or more and to avoid washout of the methanogens [51]. It is however reported that Methanosarcina sp. have high growth rates (i.e., doubling times in the order of 1.0 to 1.2 days) and are tolerant to sudden changes in $\mathrm{pH}$ of around 0.8-1.0 units caused by overloading, compared to the other methanogens, which have doubling times of minimum 4-6 days and tend to be affected by a $\mathrm{pH}$ shock of 0.5 units or even less [52-54]. Methanosarcina sp. are able to use both the acetoclastic and the hydrogenotrophic methanogenesis pathway, making them more tolerant to specific inhibitors of the acetoclastic pathway, such as fluoroacetate and methyl fluoride, compared to Methanosaeta sp. [53, 55]. They are tolerant to levels of ammonium up to $7000 \mathrm{mg} \mathrm{TAN} \mathrm{L}^{-1}$ (total ammonia nitrogen) as well $[56,57]$. These Methanosarcina sp. are therefore able to achieve stable growth at low retention times (even as low as 4 days), high organic loading rates, and high levels of, for example, ammonium [52, 57].

\subsubsection{Methanosarcina as Inoculum Species for Bioaugmen-} tation. Severe impairment of the methanogenic community terminates the methane production [47-49]. Regeneration of the anaerobic digester can then be achieved by interruption of the feeding of the reactor and allowing the methanogens to restore or by replacing them entirely by anaerobic biomass in the digester. Neither option is economically very easy, thus enforcing the need for other solutions to solve the problem. The addition of an inoculum rich in Methanosarcina sp. can offer perspectives to tackle the problem. The specific features of the Methanosarcina sp. (i.e., high tolerance to several impairments, as described above) make them suitable for establishing the regeneration of the anaerobic digester if methanogenesis has ceased due to environmental factors. The disadvantage of the addition of Methanosarcina sp. rich anaerobic sludge lies within the limited removal of the residual acetate, which has accumulated most likely due to the uncoupling of the acetogenic bacteria and the methanogens, because of the high Ks value of Methanosarcina sp. for acetate $[52,58,59]$. The addition of a Methanosarcina sp. rich inoculum can initiate two different scenarios in the anaerobic digester. In the first case, the Methanosarcina sp. could start to grow fast, because of a high Umax and cause the methanogenic community to evolve towards a Methanosarcina sp. dominated community with enhanced stability. In the other case, the Methanosarcina sp. could temporarily grow, ameliorating the conditions which initially caused the methanogenesis to cease and then decline again in abundance or disappear totally from the system, because of the regained dominance of Methanosaeta sp. at concentrations of acetate below $100 \mathrm{mgL}^{-1}[52,59]$. Both scenarios, however, will revive the methanogenesis in the anaerobic digester.

Anaerobic digesters normally host a diverse methanogenic community, containing both acetoclastic and hydrogenotrophic methanogens, thus enhancing reactor stability 


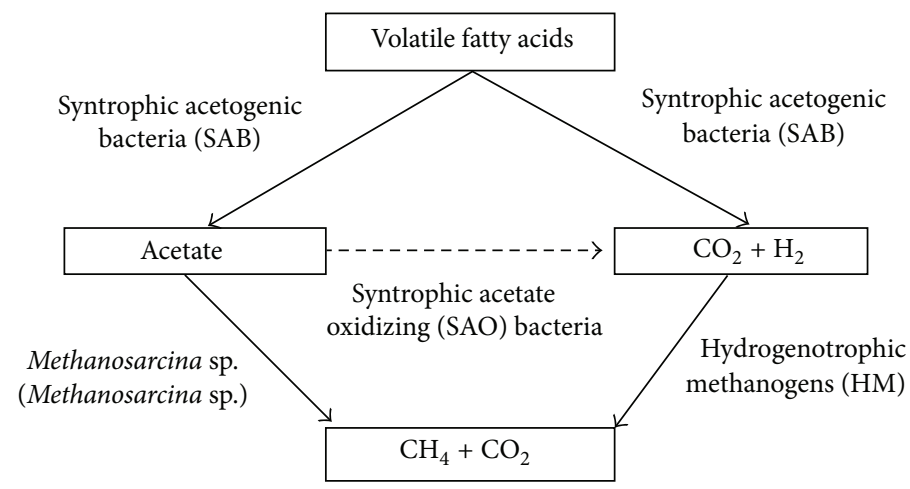

FIGURE 2: Methanogenesis in anaerobic digestion as documented for normal waste treatment reactor systems [42]. The SAB consist mostly of Clostridium sp. at both mesophilic and thermophilic conditions [43]. The hydrogenotrophic methanogens in both mesophilic and thermophilic anaerobic digesters belong to the two orders of Methanobacteriales and Methanomicrobiales [44].

$[60,61]$. Methanosarcina sp. are however able to convert both acetate and $\mathrm{CO}_{2}$ with $\mathrm{H}_{2}$ to methane [55]. Other compounds can also be converted to methane by Methanosarcina sp., as mentioned above $[55,62,63]$. The ability of Methanosarcina sp. to convert these compounds to methane thus makes the presence of other methanogens in the anaerobic digester redundant.

It can therefore be stated that an anaerobic digester, entirely based on Methanosarcina sp., would still be able to achieve stable methanogenesis. The creation of an anaerobic digester entirely based on Methanosarcina, under normal nonstressed growth conditions, would require a decrease of the SRT to a value as low as 3-5 days, since Methanosarcina sp. have low doubling times, compared to Methanosaeta sp. $[55,59]$. Yet taking into account their tolerance to several impairments (e.g., high ammonium and salt concentrations and high concentrations of VFA, correlated to a high OLR), an anaerobic digester with a retention time below 5 days would be based almost entirely on Methanosarcina and beable to handle severe impairments and organic loading rates [57, 64-66]. A Methanosarcina sp. based anaerobic digester would be able to handle higher amounts (Figure 2). Proposed robust methanogenesis system is based on syntrophic acetate oxidizing (SAO) bacteria and Methanosarcina for intensive energy production reactor systems. The SAB consist mostly of Clostridium sp. at both mesophilic and thermophilic conditions [43]. Syntrophic acetate oxidizing bacteria can be located in both mesophilic (Clostridium ultunense and Syntrophaceticus schinkii) and thermophilic (Thermacetogenium phaeum and Thermotoga lettingae) conditions [18, 57, 61, 6769]. Methanosarcina and Methanobacteriales are postulated to be the dominant hydrogenotrophic methanogens at both mesophilic and thermophilic conditions of organic waste, because of the low sludge retention time of 3-5 days, compared to conventional anaerobic digesters, which have an SRT in the order of 20-30 days [51]. The disadvantage however of this system will be the elevated concentrations of residual VFA, especially acetate, in the output, because of the high Ks value of Methanosarcina sp. for acetate, imposing the need.

In anaerobic digestion, methanogenesis occurs through two pathways, that is, the direct cleavage of acetate to $\mathrm{CH}_{4}$ and
$\mathrm{CO}_{2}$ (acetoclastic methanogenesis) and the reduction of $\mathrm{CO}_{2}$ with hydrogen gas (hydrogenotrophic methanogenesis). The contribution of each pathway to the methanogenesis depends on the inoculum sludge, the organic substrate, and the process conditions [11]. It is to be expected that acetate, which is formed during acetogenesis from, for example, propionate, ethanol, and lactate, will be directly converted to methane by the acetoclastic methanogens. Hydrogen gas and $\mathrm{CO}_{2}$, formed during hydrolysis, acidogenesis and acetogenesis, will be converted to methane by hydrogenotrophic methanogens (Figure 1). Yet part of the acetate can be oxidized to hydrogen gas and $\mathrm{CO}_{2}$, depending on the reactor conditions, by syntrophic acetate oxidizing ( $\mathrm{SAO}$ ) bacteria, instead of being directly converted to methane by the acetoclastic methanogens $[67,70]$. Syntrophic acetate oxidizing bacteria have been detected in both mesophilic (Clostridium ultunense and Syntrophaceticus schinkii) and thermophilic (Thermacetogenium phaeum and Thermotoga lettingae) conditions [18, $43,57,61,67,68]$. The $\mathrm{pH}$ range of these syntrophic acetate oxidizing bacteria varies between 6.0 and 8.0, with a $\mathrm{pH}$ of 7 being the optimal value. Several Clostridium sp., that is, potential acetate oxidizing partners in the syntrophic relationship, are however still able to grow at a $\mathrm{pH}$ of 5.0, thus making syntrophic acetate oxidizing bacteria able to remain active at slightly or even heavily deteriorated conditions in anaerobic digestion $[43,69]$. The syntrophic oxidation of acetate to $\mathrm{H}_{2}$ and $\mathrm{CO}_{2}$ is however thermodynamically very unfavorable $\left(\mathrm{DG} 00=104.6 \mathrm{~kJ} \mathrm{~mol}^{-1}\right)$. As a result, syntrophic acetate oxidation can only take place at very low values of $\mathrm{H}_{2}$ partial pressure, that is, between 2.6 and $74 \mathrm{~Pa}$ [67]. Only in this narrow interval of hydrogen gas concentrations, the syntrophic acetate oxidation and the subsequent hydrogenotrophic methanogenesis (SAO-HM) coupling are thermodynamically possible [67]. Hence these acetate oxidizing bacteria require partner organisms, which they find in hydrogenotrophic methanogens [61, 67]. Nevertheless, this indirect conversion of acetate to methane has the disadvantage that the available energy has to be divided over two organisms instead of one in the case of the direct cleavage of acetate to methane and $\mathrm{CO}_{2}$, thus questioning the benefit of a two-organism system. The answer lies in 
the sensitivity of the acetoclastic Methanosaeta sp. towards different impairments causing a shift in acetate degradation from direct acetate cleavage towards syntrophic acetate oxidation coupled with hydrogenotrophic methanogenesis [70]. This shift of a Methanosaeta sp. dominated system towards a hydrogenotrophic methanogens dominated methanogenic community has been reported at elevated ammonium concentrations in the range of $3000 \mathrm{mg} \mathrm{TAN} \mathrm{L}^{-1}[57,61,70]$. An increase in the organic loading rate, causing the accumulation of fatty acids, especially acetic acid, also leads to a shift towards syntrophic acetate oxidation and hydrogenotrophic methanogenesis [70, 71]. An increase of the accumulated acetate concentration up to a value of $3000 \mathrm{mg} \mathrm{COD} \mathrm{L}^{-1} \mathrm{can}$ be considered as the threshold for the shift in the methanogenesis pathway $[58,71]$. The reactor temperature influences the dominant pathway as well, as acetoclastic methanogenesis is favored at mesophilic conditions, whereas SAO-HM becomes the dominant pathway at thermophilic temperatures $[58,70]$. The free energy change of the syntrophic oxidation of acetate and subsequent hydrogenotrophic methanogenesis amounts to $36 \mathrm{~kJ} \mathrm{~mol}^{-1}$ at $25^{\circ} \mathrm{C}$ and $42 \mathrm{~kJ} \mathrm{~mol}^{-1}$ at $58^{\circ} \mathrm{C}$, thus explaining the dominance of syntrophic acetate oxidation at elevated temperatures [18]. High ammonium concentrations and elevated acetate levels seem to suppress the growth of Methanosaeta sp. and therefore enhance the SAO-HM. Yet, Methanosarcina is also able to tolerate these enhanced concentrations and is both acetoclastic and hydrogenotrophic $[52,55]$. Given this information, the coupled growth of syntrophic acetate oxidizing bacteria and Methanosarcina sp. may enhance reactor stability. Elevated concentrations of fatty acids and ammonium lead to a rise in the abundance of both SAO and Methanosarcina sp., although at the cost of a severe decline in the abundance of Methanosaeta sp., demonstrating the tolerance of this partnership to several environmental factors $[57,70]$. The success of this partnership can possibly be due to the formation of nanowires between the SAO and Methanosarcina. It has already been reported that nanowires can be formed between Geobacter sp. and methanogens in anaerobic digesters and it seems therefore not unlikely that other species may succeed in achieving direct interspecies electron transfer in anaerobic digesters [72, 73]. The unique S-layer of Methanosarcina sp. together with the possibility of energy conservation by means of direct electron transfer makes the SAO-HM partnership very suitable for DIET [74]. A robust methanogenic process can therefore be established, based on the interaction between SAO and Methanosarcina sp. with acetoclastic methanogenesis by Methanosarcina sp. at low OLR and ammonium concentrations and syntrophic acetate oxidation coupled with hydrogenotrophic methanogenesis by Methanosarcina sp. at elevated OLR and ammonium concentrations (Figure 2). An anaerobic digester based on this system will not require a population change at abrupt impairments but only a change in methanogenesis physiology by Methanosarcina sp., which will greatly decrease the response time of anaerobic digesters to perturbations.
4.2.5. Cellulosic Microorganism. Cellulose is the most abundant biopolymer on earth and also a significant part of solid wastes. The cellulosic waste can be anaerobically digested to methane, which is a source of energy for heating, cooking, electricity, or car fuel [6]. Depolymerization followed by solubilization of the polymers is the first step in anaerobic digestion of solid wastes. After that, cellulose degradation products (i.e., cellobiose and higher order soluble cellodextrins) can be converted to methane and carbon dioxide through acidogenesis, acetogenesis, and methanogenesis processes $[75,76]$. The methanogenesis phase is normally considered as the rate-limiting step for anaerobic digestion of easy-to-digest substrates, because of the slow growth rate of the methanogenic bacteria. However, during anaerobic digestion of cellulose, several studies have rather pointed out the bacterial hydrolysis phase as the rate-limiting step [77]. Consequently, there is considerable interest in developing efficient pretreatments of cellulose to increase the rate of solubilization during anaerobic digestion. Two major questions need answers before this progress can be realized. Firstly, the structural features of cellulose need to be altered to enhance its solubilization rate. Secondly, what impact would augmented cellulose solubilization have on the rest of the digestion process? To meet the first question, (a), alteration of crystallinity, accessible internal surface area, and degree of polymerization, three major physicochemical and structural parameters, may increase the digestibility of cellulosic substrates $[78,79]$. Although evaluation of these fine-structure parameters and their relative importance to cellulose hydrolysis is not easy, the crystallinity and accessible internal surface area have been reported to be the most important factors influencing the enzymatic hydrolysis rate of cellulose. Several studies have shown that the crystallinity of cellulose is the most important factor, with amorphous cellulose being more ready for digestion by fungal enzymes than high-crystalline cellulose [76, 78]. Nevertheless, other studies have reported that their available surface area is a more important factor in utilization of cellulose by whole-cell systems $[80,81]$. The mechanism by which cellulose digestion occurs is by means of anaerobic microorganisms excreting cellulosome on the outside surface of their cell wall and attaching themselves to the surface of the cellulose particles, and hence causing hydrolysis. Therefore, cellulosome is more efficient compared to the free fungal cellulase system [82, 83]. The available surface area for hydrolysis bacteria to be attached is therefore an important determinant of the hydrolysis rate. Moreover, the degree of crystallinity does not have a significant impact on the rate of cellulose degradation by ruminal microorganisms [81]. It was later confirmed [84] that no significant difference between the solubilization rates of microcrystalline cellulose and amorphous cellulose exists. In consequence, the effect of cellulose structure on its solubilization rate in anaerobic digestion has not been adequately elucidated and thus question (a) above still needs to be tackled. Addressing the second question (b), it is known that in anaerobic digestion the degradation steps are linked and influence each other. However, this network is still not fully characterized [85] having recently investigated the digestion of microcrystalline cellulose at high organic loading 
rates (OLR) between 5.7 and $34.3 \mathrm{gVS} / \mathrm{L}$. They increased the OLR gradually. Because of high adaptation level of microbial biocenosis, with every increase of OLR, the only sign of system stress was increasing total degradation time [85].

4.3. Enzymatic Hydrolysis of Plant Cell Wall. Because plant cell walls are relatively complex structures, a great variety of enzymes are needed for extensive enzymatic hydrolysis. Only three readily cultivable species of ruminal bacteria (Ruminococcus albus, Ruminococcus flavefaciens and Fibrobacter succinogenes) are found in high numbers in the rumen and are capable of rapid growth on cellulose [86]. The most extensively studied strains of these species appear to degrade cellulose at rates similar to that in the rumen itself $\left(0.1 \mathrm{~h}^{-1}\right)$. These rates exceed those of most cellulolytic microbes, except for some thermophilic bacteria (e.g., approximately $0.16 \mathrm{~h}^{-1}$ for Clostridium thermocellum) [78]. In the ruminococci, fibrolytic enzymes appear to be organized into cellulosomal complexes that display similarity to the well-studied cellulosomes of C. thermocellum [87]. F. succinogenes represents something of an outlier among anaerobic cellulose degraders. This species can produce more than 100 polysaccharide hydrolases, most of which are retained on the cell surface. However, it does not produce cellulosomal structures, and its genome lacks certain essential cellulosomal components, particularly the cipA gene that encodes the Scaffolding protein, the $m$ primary structural feature of the cellulosome [88]. A key observation regarding the ruminal fermentation is that virtually the entire spectrum of polysaccharides in plant biomass (cellulose, most hemicelluloses, pectin, starch, and fructans) are readily hydrolyzed and ultimately fermented by one or more members of the microbial population [89]; no small feat in those plant cell walls may contain several dozen different linkage types [90].

Fermentation of the products of polysaccharide hydrolysis yields a mixture of VFA as wells as methane and $\mathrm{CO}_{2}$ (Figure 1), and the relative proportions of these products are clearly diet dependent. For purposes of analysis, we shall use the carbohydrate molar fermentation balance described by [86]

$$
\begin{aligned}
58 \text { Hexose }= & 62 \text { Acetic acid }+22 \text { Propionic acid } \\
& +16 \text { Butyric acid }+60.5 \mathrm{CO}_{2} \\
& +33.5 \mathrm{CH}_{4}+27 \mathrm{H}_{2} .
\end{aligned}
$$

Plant cell walls have an abundance of cellulose and hemicelluloses that are a major determinant of the total amounts of VFA produced. However, the cytoplasmic contents of forages contain substantial amounts of protein, lipid, and nucleic acids [91]. Bioconversion systems that employ pure cultures of microorganisms typically lack enzymes needed to digest all of this material, but the rumen is inhabited by highly complex ecosystem of microorganisms that has been selected to degrade virtually all of the organic constituents of plants except lignin [92]. The products of protein fermentation include ammonia and the major VFAs (acetate, propionate, and butyrate), as well as other longer chain VFA (isobutyrate, valerate, isovalerate, and 2-methylbutyrate).
Although the fermentation products of individual amino acids may vary widely [86], ratios of the major VFAs in the rumen do not appear to shift dramatically with different levels of protein in the diet $[93,94]$ suggesting that, when averaged out across all substrates within their class, carbohydrates and proteins have rather similar fermentation patterns. Nucleic acids are fermented by several known ruminal bacterial species [95]; fermentation end-products have not been examined, but are likely to include VFA, $\mathrm{NH}_{3}$, and $\mathrm{CO}_{2}$. Lipid degradation occurs through hydrolysis of triglycerides and fermentation of the resulting glycerol; the long-chain free fatty acids are typically not fermented, although unsaturated acids may be reduced or isomerized [96] prior to their absorption.

4.3.1. Structure of Cellulose. Cellulose is a linear polymer that is composed of D-glucose subunits linked by $\beta-1,4$ glycosidic bonds forming the dimer cellobiose. These form long chains (or elemental fibrils) linked together by hydrogen bonds and van der Waals forces. Cellulose is usually present as a crystalline form and a small amount of nonorganized cellulose chains forms amorphous cellulose. In the latter conformation, cellulose is more susceptible to enzymatic degradation [97]. Cellulose appears in nature to be associated with other plant compounds and this association may affect its biodegradation. Hemicellulose is a polysaccharide with a lower molecular weight than cellulose. It is formed of $\mathrm{D}$-xylose, $\mathrm{D}$-mannose, $\mathrm{D}$-galactose, $\mathrm{D}$-glucose, $\mathrm{L}$-arabinose, 4-O-methyl-glucuronic, D-galacturonic, and D-glucuronic acids. Sugars are linked together by $\beta-1,4$ - and sometimes by $\beta$-1,3-glycosidic bonds. The main difference between cellulose and hemicellulose is that hemicellulose has branches with short lateral chains consisting of different sugars and cellulose consists of easily hydrolyzable oligomers. Lignin is linked to both hemicellulose and cellulose, forming a physical seal that is an impenetrable barrier in the plant cell wall. It is present in the cellular wall to give structural support, impermeability, and resistance against microbial attack and oxidative stress. It is an amorphous heteropolymer, nonwater soluble and optically inactive that is formed from phenylpropane units joined together by non-hydrolyzable linkages. This polymer is synthesized by the generation of free radicals, which are released in the peroxidasemediated dehydrogenation of three phenyl propionic alcohols: coniferyl alcohol (guaiacyl propanol), coumaryl alcohol (p-hydroxyphenyl propanol), and sinapyl alcohol (syringyl propanol). This heterogeneous structure is linked by $\mathrm{C}-\mathrm{C}$ and aryl-ether linkages, with aryl-glycerol and $\beta$-aryl ether being the predominant structures [98]. The metabolism of various organics for biogas generation has been given in Figure 3.

\section{Different Inocula for Biogas Production}

Different stages of anaerobic digestion contain considerably varied species of symbiotic microorganisms, which can be broadly classified as two groups: acidogens and methanogens. Since the methanogenic reaction is believed to be the ratelimiting step in the overall anaerobic digestion, proper 


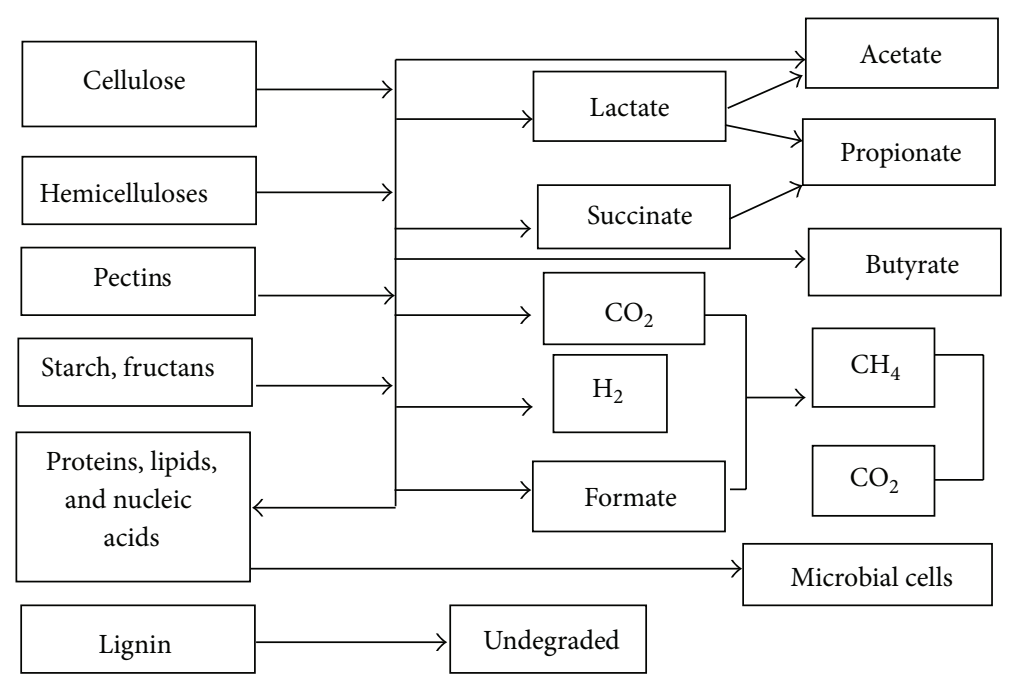

FIGURE 3: General scheme of biopolymer fermentation in the rumen. Products in boxes with darker borders are final products of the ruminal fermentation, while compounds in light-bordered boxes are intermediates [45].

control of the methanogenic phase has been a key factor in the successful operation of most anaerobic processes [99]. Specifically, methane production is carried out by methanogenic groups belonging to Archaea, which are known to have very sensitive growth and activity behaviors concerning different substrates and operation conditions [56]. The stable formation of the methanogenic community determines the success or failure in anaerobic digestion systems treating wastewaters including highly concentrated organic and toxic materials (e.g., highly concentrated ammonia or acetate), such as swine wastewater.

5.1. Effect of Inoculum Source. The inoculum used for anaerobic digestion plays a vital role in the way it will degrade the organic matter and produce biogas and also affect the amount of biogas in some cases [100]. The inocula from different sources are normally utilized under the same operating conditions such as mesophilic temperature and around neutral $\mathrm{pH}$, the respective microbial communities vary in many aspects like profile of extracellular enzymes, species profile, biofilm forming behavior, nutritional requirements, and physiological characteristics [26]. Microbial activities and chemical composition of inoculum's consortia greatly affect the performance of biogas production particularly from lignocellulosic biomass [20]. The source of inoculum not only affects the amount of biogas production but also influences the kinetics of the process of anaerobic digestion. It has been reported in the variation in the amount and kinetics of biogas production during solid state anaerobic digestion of corn stover using inocula from different origins [28]. The selection of inocula to startup a full scale digester is crucial and plays an important role in overcoming the acidification. If an active inoculum is selected, process failure can be avoided during the startup phase [101]. The selection of source of the inocula is based on the activity; hence selection of the active inocula will reduce the amount of the inocula required for the operation of a full scale digester and consequently the volume of the digester [102]. Origins of inocula used by many researchers are from anaerobic digester treating municipal wastewater sludge, cattle manure, food waste, or combinations. However, the inocula from anaerobic digester treating municipal wastewater sludge are expected to have diverse groups of active microorganisms hence being suitable for many different sources of microorganisms. Inoculum source is also a very important operational parameter. Also, it is crucial for the selection of waste/inocula ratio as well as the assessment of anaerobic biodegradability of solid wastes [103]. In dry-thermophilic digestion, the inoculum source and the total solid percentage selected are responsible for accomplishing rapid onset of a balanced microbial population. The systematicness of inoculation, the percentage of inoculation, and wetting procedure differ between processes proposes by several authors. The percentage of inoculation for acidogenic fermentation of organic urban wastes is approximately 30\% weight/weight (w/w) [104]. In case of the anaerobic biodegradability of solid waste, the use of a highly active anaerobic inocula or animal inoculum waste will reduce significantly the experimental time or reduce the amount of inocula required in full scale batch digesters and consequently the corresponding digester volume [105].

The effect of inoculum source on anaerobic thermophilic digestion of separately collected organic fraction of municipal solid wastes was investigated [106]. Laboratory scale reactors $(\mathrm{V}: 1.1 \mathrm{~L})$ were evaluated using six different inocula sources: (1) corn silage (CS); (2) digested restaurant waste mixed with rice hulls (RH_OFMSW); (3) cattle excrement (CATTLE); (4) swine excrement (SWINE); (5) digested sludge (SLUDGE); and (6) SWINE mixed with SLUDGE $(1: 1)$ (SWINE/SLUDGE). Sludge is the best inoculum source for anaerobic thermophilic digestion of the treatment of organic fraction of municipal solid waste at dry conditions (30\% TS). Over 60 days operating period, it was confirmed that SLUDGE reactor can achieve $44.0 \%$ COD removal efficiency and $43.0 \% \mathrm{VS}$ removal. In stabilization phase, 
SLUDGE reactor showed higher volumetric biogas generated of $78.9 \mathrm{~mL} /$ day (or $35.6 \mathrm{~mL} \mathrm{CH}_{4} /$ day) reaching a methane yield of $0.53 \mathrm{~L} \mathrm{CH}_{4} / \mathrm{g}$ VS. Likewise, SWINE/SLUDGE and SWINE were also good inocula [106].

Inocula play an important role in anaerobic reactor startup by balancing the populations of syntrobacter and methanogens. Such balance makes syntrophic metabolism thermodynamically feasible in anaerobic digestion. The effect of inocula on performance of dairy manure digestion after the examinations of microcolonies in the granular, nongranular, and dairy manure suggests that syntrophic occurrence of methanogens and syntrophobacter in granular inocula was common while it was less visible in nongranular and completely absent in dairy manure. The scanning electron microscope and transmission electron microscope images show the variations in the juxtaposition and bacterial population level in different inocula and these were linked with biogas production in different treatments, granular sludge, nongranular sludge, and mixed culture from anaerobic lagoon and the control did not receive exogenous inocula, demonstrating the importance of syntrophic association and population level of different groups of bacteria in anaerobic digester performance [107].

Cellulose solubilization is the rate determining step in the anaerobic digestion of organic solid waste $[3,77,108]$. An increase in the rate of solubilization should lead to an increase in the overall efficiency of the anaerobic digestion process. Reactor studies on cellulose solubilization rates are typically conducted in anaerobic, mesophilic environments with approximately neutral $\mathrm{pH}$ and may be inoculated from a range of source environments including landfill leachate, manure, sewage sludge, anaerobic digesters, or the rumen [109-118]. Despite similarities in the operating conditions of reactors inoculated from different source environments, the respective microbial communities may differ in many respects, including their species profile, biofilm architecture, nutritional requirements, particle colonization, and hydrolysis rates. Microbial communities in cellulolytic environments are highly complex with interactions among numerous trophic groups required to carry out the digestion process [113, 116, 119-121]. Fibrobacter succinogenes, Ruminococcus albus, and Ruminococcus flavefaciens are dominant cellulose degrading bacteria in the rumen [122], while Clostridium species tend to be dominant in landfills and anaerobic digesters [111, 123].

Cellulose solubilization kinetics from controlled batch digestions were investigated [26]. Separate measurements and analyses were performed for sessile biomass (biofilms) and planktonic biomass (free suspensions). Experiments were conducted using either leachate enriched on cellulose or rumen fluid as inocula to assess if the effect of biomass concentration was consistent for microbial populations from different source environments in the batch. The correlation between solubilization rate and sessile biomass was statistically the same for the rumen and leachate inoculated reactors indicating that at low concentration ratios of inocula to cellulose, the rate of cellulose solubilization is dependant primarily on sessile biomass concentration rather than the species profile of the cellulolytic community [26]. The effect of various inocula on biogas production has been shown in Table 4.

The results of thermophilic methanogens in turf used as inoculums show that Methanoculleus sp. regarded as hydrogenotrophic and Methanosarcina sp. regarded as acetoclastic methanogens were present in turf tested. However, active acetoclastic methanogens were present in turf soil only. The thermophilic methanogens were present in various turf grass species: Stenotaphrum secundatum, Cynodon dactylon, and Zoysia japonica. A dried and pulverized grass extract that could be generated can serve as a readily storable methanogenic inocula for thermophilic anaerobic digestion. The methanogens could also be physically extracted into an aqueous suspension, suitable for inocula [124].

Sea wrack (dislodged sea grasses and seaweeds) was used in biogas production. Fresh water scarcity in island communities where sea wrack could accumulate led to seawater utilization as liquid substrate. Three microbial seeds cow manure (CM), marine sediment (MS), and sea wrack-associated microflora (SWA) were explored for biogas production. The average biogas produced was $2172 \pm 156 \mathrm{~mL}$ (MS), $1223 \pm 308 \mathrm{~mL}$ (SWA), and $551 \pm 126 \mathrm{~mL}(\mathrm{CM})$. Though methane potential (396.9 $\mathrm{mL} \mathrm{CH}_{4} \mathrm{~g}^{-1}$ volatile solid) computed from sea wrack proximate values was comparable to other feedstocks, the highest methane yield was low (MS $=94.33 \mathrm{~mL} \mathrm{CH}_{4} \mathrm{~g}^{-1} \mathrm{VS}$ ). Among the microbial seeds, MS proved to be the best microbial source in utilizing sea wrack biomass and seawater. However, salinity $(\mathrm{MS}=42 \%)$ observed exceeded average seawater salinity (3). Hence, methanogenic activity could have been inhibited. This is the first report on sea wrack biomass utilization for thalassic biogas production [125].

The biomethanization of food waste had three different total solid percentages $(20 \%, 25 \%$, and $30 \%)$ with two different inocula percentages $(20-30 \%)$ of mesophilic municipal sludge. The best performance for food waste biodegradation and methane generation was the reactor with $20 \%$ of total solids and $30 \%$ of inocula gives rise to an acclimation stage with acetogenic/acetogenic activity between 20 and 60 days and methane yields of $0.49 \mathrm{~L} \mathrm{CH}_{4} / \mathrm{g}$ VS [126].

The conducted BMP test explored the influence of using two different anaerobic inocula sources on the digestion of food waste: digested sludge from a municipal wastewater treatment plant and from a digester treating the organic fraction of municipal solid wastes. The inoculum from an anaerobic digester treating municipal wastewater sludge was superior to the inocula from anaerobic digester treating food waste in digesting food waste [127].

Fish waste (FW) obtained from a fish processor was ensiled for biogas production. The FW silages were prepared by mixing FW with bread waste (BW) and brewery grain waste (BGW), and the quality of the prepared silages was evaluated. The biogas and methane yield for FW silages after 96 days was calculated to be $671-763 \mathrm{~mL} / \mathrm{g}$ VS and $441-$ $482 \mathrm{~mL} / \mathrm{g}$ VS, respectively [128]. 
TABLE 4: Various inocula along various substrates and their potential for biogas production.

\begin{tabular}{|c|c|c|c|c|c|c|}
\hline Inocula & Pretreatment & Substrate & $S / I$ ratio & $\begin{array}{c}\text { Biogas } \\
\text { production }\end{array}$ & Methane production & Reference \\
\hline Cow manure & NG & $\begin{array}{l}\text { Sea wrack } \\
\text { (dislodged sea } \\
\text { grasses and } \\
\text { sea weeds) }\end{array}$ & NG & $551 \pm 126 \mathrm{~mL}$ & $\begin{array}{l}396.9 \mathrm{mLCH}_{4} \mathrm{~g}^{-1} \\
\text { (volatile solid) }\end{array}$ & {$[125]$} \\
\hline $\begin{array}{l}\text { Marine } \\
\text { sediments }\end{array}$ & NG & Sea wrack & NG & $2172 \pm 156 \mathrm{~mL}$ & & {$[125]$} \\
\hline $\begin{array}{l}\text { Sea wrack } \\
\text { associated } \\
\text { microflora }\end{array}$ & NG & Sea wrack & NG & $1223 \pm 308 \mathrm{~mL}$ & & {$[125]$} \\
\hline $\begin{array}{l}\text { Municipal } \\
\text { Sludge }\end{array}$ & NG & Food waste & NG & $\mathrm{NG}$ & $0.49 \mathrm{~L} \mathrm{CH}_{4} / \mathrm{g} \mathrm{VS}$ & {$[126]$} \\
\hline $\begin{array}{l}\text { Municipal } \\
\text { wastewater } \\
\text { sludge }\end{array}$ & & Food waste & $\begin{array}{c}1 \\
0.5 \\
0.25 \\
\end{array}$ & NG & $\begin{array}{c}660 \mathrm{~mL} \mathrm{CH}_{4} / \mathrm{g} \mathrm{VSS}_{\text {sub }} \\
790 \mathrm{~mL} \mathrm{CH}_{4} / \mathrm{g} \mathrm{VSS}_{\text {sub }} \\
490 \mathrm{~mL} \mathrm{CH}_{4} / \mathrm{g} \mathrm{VSS}_{\text {sub }}\end{array}$ & {$[127]$} \\
\hline $\begin{array}{l}\text { Inocula from } \\
\text { food waste }\end{array}$ & & Food waste & $\begin{array}{c}1 \\
0.5 \\
0.25 \\
\end{array}$ & NG & $\begin{array}{l}1000 \mathrm{~mL} \mathrm{CH} 4 / \mathrm{g} \mathrm{VSS}_{\text {sub }} \\
940 \mathrm{~mL} \mathrm{CH} 4 / \mathrm{g} \mathrm{VSS}_{\text {sub }} \\
1400 \mathrm{~mL} \mathrm{CH} / \mathrm{g} \mathrm{VSS}_{\text {sub }}\end{array}$ & {$[127]$} \\
\hline $\begin{array}{l}\text { Inocola from } \\
\text { WWTP }\end{array}$ & Preincubated & $\begin{array}{l}\text { Primary } \\
\text { sludge }\end{array}$ & $\begin{array}{c}0.5 \\
1 \\
2 \\
4 \\
0.5 \\
1 \\
2 \\
4\end{array}$ & NG & $\begin{array}{l}241 \mathrm{mLCH}_{4} / \mathrm{g} \mathrm{VSS}_{\text {sub }} \\
221 \mathrm{~mL} \mathrm{CH}_{4} / \mathrm{g} \mathrm{VSS}_{\text {sub }} \\
235 \mathrm{~mL} \mathrm{CH}_{4} / \mathrm{g} \mathrm{VSS}_{\text {sub }} \\
273 \mathrm{~mL} \mathrm{CH}_{4} / \mathrm{g} \mathrm{VSS}_{\text {sub }} \\
283 \mathrm{~mL} \mathrm{CH}_{4} / \mathrm{g} \mathrm{VSS}_{\text {Sub }} \\
231 \mathrm{~mL} \mathrm{CH}_{4} / \mathrm{g} \mathrm{VSS}_{\text {Sub }} \\
230 \mathrm{~mL} \mathrm{CH}_{4} / \mathrm{g} \mathrm{VSS}_{\text {Sub }} \\
235 \mathrm{~mL} \mathrm{CH}_{4} / \mathrm{g} \mathrm{VSS}_{\text {Sub }}\end{array}$ & [127] \\
\hline Digester sludge & NG & Bulrush & NG & NG & $\begin{array}{c}464.3 \mathrm{~g} \mathrm{COD} / \mathrm{g} \text { total } \\
\text { solids }\end{array}$ & {$[162]$} \\
\hline Digester sludge & $\begin{array}{c}\text { Steam } \\
\text { explosion }\end{array}$ & Bulrush & NG & $\mathrm{NG}$ & $14.5 \%$ & {$[162]$} \\
\hline Rumen fluid & NG & Bulrush & NG & NG & $362.8 \mathrm{~g} \mathrm{COD} / \mathrm{g}$ TS & {$[162]$} \\
\hline Rumen fluid & $\begin{array}{c}\text { Steam } \\
\text { Explosion }\end{array}$ & Bulrush & NG & NG & $18.5 \%$ & {$[162]$} \\
\hline $\begin{array}{l}\text { Mesophilic } \\
\text { anaerobic } \\
\text { digester }\end{array}$ & Ensiling & Fish waste & NG & $\begin{array}{c}671- \\
763 \mathrm{~mL} / \mathrm{g} \mathrm{VS}\end{array}$ & $441-482 \mathrm{~mL} / \mathrm{g} \mathrm{VS}$ & {$[128]$} \\
\hline $\begin{array}{l}\text { Thermophilic } \\
\text { anaerobic } \\
\text { sludge }\end{array}$ & $\begin{array}{c}\text { Mixing with } \\
\text { distillery } \\
\text { wastewater }\end{array}$ & $\begin{array}{l}\text { Cassava } \\
\text { residues }\end{array}$ & NG & NG & $259.46 \mathrm{~mL} / \mathrm{g} \mathrm{VS}$ & {$[131]$} \\
\hline $\begin{array}{l}\text { Mesophilic } \\
\text { activated } \\
\text { sludge }\end{array}$ & $\begin{array}{l}\text { Biological } \\
\text { thermal } \\
\text { ultrasound }\end{array}$ & Microalgae & 0.5 & $\begin{array}{c}\text { Negligible } \\
46-62 \% \\
6-24 \% \\
\end{array}$ & NG & {$[163]$} \\
\hline $\begin{array}{l}\text { Mesophilic } \\
\text { activated } \\
\text { sludge }\end{array}$ & & Microalgae & 0.5 & $188-395 \mathrm{~mL}$ & NG & {$[163]$} \\
\hline Rumen fluids & NG & Cattle manure & $\begin{array}{l}17.64 \\
23.51 \\
35.27 \\
70.54 \\
\end{array}$ & NG & $\begin{array}{l}191 \mathrm{~mL} / \mathrm{g} \text { VS } \\
162 \mathrm{~mL} / \mathrm{g} \text { VS } \\
144 \mathrm{~mL} / \mathrm{g} \text { VS } \\
112 \mathrm{~mL} / \mathrm{g} \text { VS }\end{array}$ & {$[164]$} \\
\hline Sludge digester & NG & $\begin{array}{l}\text { Municipal } \\
\text { solid waste }\end{array}$ & $\begin{array}{c}2 \mathrm{~g} \mathrm{VM}_{\text {inoculum }} / \\
\mathrm{g} \mathrm{VM}_{\text {waste }}\end{array}$ & NG & $150 \mathrm{~mL} \mathrm{~g} \mathrm{DM}^{-1}$ & {$[165]$} \\
\hline
\end{tabular}


A mesophilic lignocellulolytic microbial consortium BYND-5, established by successive subcultivation, was applied to enhance the biogas production. The degradation efficiency of BYND-5 for rice straw was more than $49.0 \pm$ $1.8 \%$ after 7 days of cultivation at $30^{\circ} \mathrm{C}$. Various organic compounds, including acetic acid, propionic acid, butyric acid, and glycerin, were detected during biodegradation. The diversity analysis of BYND-5 was conducted by ARDRA (amplified ribosomal DNA restriction analysis) of the 16S rDNA clone library. Results indicated that bacterial groups represented in the clone library were the Firmicutes (5.96\%), the Bacteroidetes (40.0\%), Deferribacteres (8.94\%), Proteobacteria (16.17\%), Lentisphaerae (2.13\%), Fibrobacteraceae $(1.7 \%)$, and uncultured bacterium (25.1\%). Additionally, the enhancement of biogas yield and methane content was directly related to the pretreatment with BYND-5. The microbial community identified herein is a potential candidate consortium for the degradation of waste lignocelluloses and enhancement of biogas production under the mesophilic temperature conditions [129].

High activity levels and balanced anaerobic microbial communities are necessary to attain proper anaerobic digestion performance. Therefore, this work was focused on the kinetic performance and the microbial community structure of six full-scale anaerobic digesters and one labscale codigester. Hydrolytic (0.6-3.5 $\mathrm{g} \mathrm{COD} \mathrm{g}^{-1} \mathrm{VSS} \mathrm{d}^{-1}$ ) and methanogenic (0.01-0.84 $\left.\mathrm{g} \mathrm{COD} \mathrm{g}^{-1} \mathrm{VSS} \mathrm{d}^{-1}\right)$ activities depended on the type of biomass, whereas no significant differences were observed among the acidogenic activities (1.5-2.2 $\mathrm{gCOD} \mathrm{g}^{-1}$ VSS $\left.\mathrm{d}^{-1}\right)$. In most cases, the higher the Bacteroidetes and Archaea percentages the higher the hydrolytic and the methanogenic activity, respectively, in the biomasses. Hydrogenotrophic methanogenic activity was always higher than acetoclastic methanogenic activity, and the highest values were achieved in those biomasses with lower percentages of Methanosaeta. In sum, the combination of molecular tools with activity tests seems to be essential for a better characterization of anaerobic biomasses [130].

In the study conducted by Regueiro et al. [130], a stable thermophilic microbial consortium with high cellulosedegradation ability was successfully constructed. Those several species of microbes coexisted in this consortium were proved by DGGE (denaturing gradient gel electrophoresis) and sequence analysis. The cooperation and symbiosis of these microbes in this consortium enhanced their cellulosedegradation ability. The pretreatment of cassava residues mixing with distillery wastewater prior to anaerobic digestion was investigated by using this microbial consortium as inocula in batch bioreactors at $55^{\circ} \mathrm{C}$. The experimental results showed that the maximum methane yield $(259.46 \mathrm{~mL} / \mathrm{g}$-VS) of cassava residues was obtained through $12 \mathrm{~h}$ of pretreatment by this microbial consortium, which was $96.63 \%$ higher than the control $(131.95 \mathrm{~mL} / \mathrm{g}$-VS). In addition, it was also found that the maximum methane yield is obtained when the highest filter paper cellulase (FPase), carboxymethyl cellulase (CMCase), and xylanase activity and soluble COD (sCOD) are produced [131].

\section{Molecular Techniques in Microbial Community Dynamics}

The increased popularity of denaturant gradient gel electrophoresis (DGGE) is reflected by the increasing number of studies that use the technique. It is based on the differing mobility on a gel of denatured DNA-fragments of the same size but with different nucleic acid sequences, thus generating band patterns that directly reflect the genetic biodiversity of the sample. The number of bands corresponds to the number of dominant species [132].

The most important application of DGGE is monitoring dynamic changes in microbial communities, especially when many samples have to be processed. There are multiple applications of DGGE related to anaerobic digestion processes: studies on differences between mesophilic and thermophilic reactors, demonstrating the lower biodiversity in thermophilic reactors used for the treatment of residual waters generated by the pharmaceutical industry [133], and analysis of the changes observed in the bacterial diversity of an anaerobic digester for treating urban solid waste [134]. Studies on the changes in bacterial communities in a continuous stirred tank reactor (CSTR) in response to dilution rate $[135,136]$ monitored changes in an ethylbenzenedegrading bacterial consortium in enrichment cultures under anaerobic, sulfate reducing conditions. By monitoring the predominant bacterial species over a period of 127 days, they identified a dominant bacterium that was present throughout the whole incubation period and most likely to be the microorganism responsible for ethylbenzene degradation. Both spatial and temporal changes in microbial community profiles were monitored by [137] in a study of expanded granular sludge bed (EGSB) reactors for the treatment of oleic acid. With this approach, the researchers were able to add another dimension to the analysis and compare the change in microbial communities in different layers of the sludge bed, as well as changes over the time. The start-up phase of garbage composters under fed batch operation was studied [138]. DGGE fingerprints revealed a significant shift in the bacterial population from ubiquinone containing microorganisms to Actinobacteria during the observation period.

Although DGGE (or TGGE: temperature gradient gel electrophoresis) is by far the most widely used genetic fingerprinting technique in molecular ecology, it is not the only method based on PCR amplification of nucleic acids and separation of the product mixture by electrophoresis. An alternative approach is the generation of SSCP (single strand conformation polymorphism) patterns; a technique that has been employed to study anaerobic digesters both on laboratory and industrial scales $[39,139]$ investigated the microbial community in a two-phase anaerobic bioreactor for the treatment of vegetable wastes with SSCP to assess changes in the composition of the bacterial and archaeal biomass. Methanogenic communities can be investigated with denaturing gradient gel electrophoresis (DGGE) analysis. The DGGE method is one of the most widely used fingerprinting technique, with the benefit of describing microbial communities by the recovery and sequencing of amplification products [140]. Therefore, it would be beneficial to figure out 


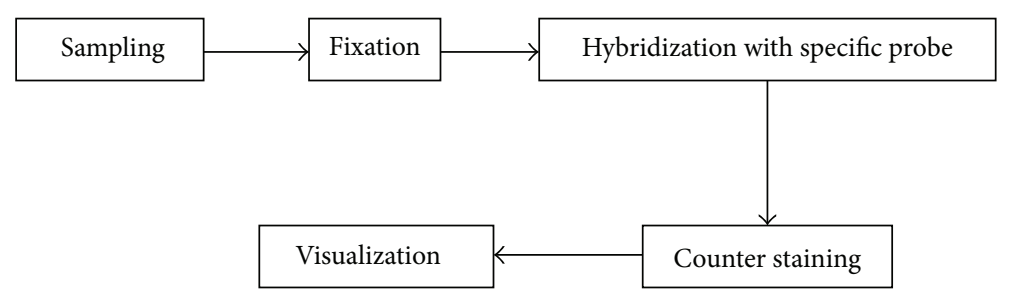

FIGURE 4: The in situ hybridization process can be divided into four stages: (A) sampling and immediate fixation in formaldehyde to preserve the integrity of the cells, especially the ribosomes; (B) hybridization with a specific probe, labelled with a fluorescent dye at its 50-end and matched with a sequence of the $16 \mathrm{~S}$ rRNA; (C) counterstaining with a universal marker (DAPI, which attaches nonspecifically to DNA molecules) or another more general probe labelled with a different fluorescent dye; (D) visualization via fluorescence microscopy. Direct quantification is possible by manual counting of hybridized cells (epifluorescence and laser confocal microscope) or by image analysis of digital photos (both microscopes) or automated counting with a flow cytometer.

the methanogenic process performance that methanogens were identified through $16 \mathrm{~S}$ rRNA-based molecular methods like DGGE.

Reactor performance and microbial community dynamics were investigated during solid state anaerobic digestion (SS-AD) of corn stover at mesophilic and thermophilic conditions. Thermophilic SS-AD led to faster and greater reductions of cellulose and hemicelluloses during the first 12 days compared to mesophilic SS-AD. However, accumulation of volatile fatty acids (VFAs) was 5-fold higher at thermophilic than mesophilic temperatures, resulting in a large $\mathrm{pH}$ drop during days 6 to 12 in the thermophilic reactors. Culture-based enumeration revealed 10-50 times greater populations of cellulolytic and xylanolytic microbes during thermophilic SS-AD than mesophilic SS-AD. DGGE analysis of PCR amplified 16S rRNA genes showed dynamic shifts, especially during the thermophilic SS-AD, of bacterial and archaeal populations over the 38 days of SS-AD as a result of acclimation of the initial seed microbial consortia to the lignocellulosic feedstock. The findings of this study can guide future studies to improve efficiency and stability of SS-AD.

The microbial community dynamics were investigated in thermal acidogenesis using mesophilic sludge through DGGE (denaturing gradient gel electrophoresis) used for the monitoring of the microbial community. The bacterial community consists of Pseudomonas mendocina, Bacillus halodurans, Clostridium hastiforme, Gracilibacter thermotolerans and Thermonas haemolytica. Among these B. halodurans, G. thermotolerans, and T. haemolytica are reported to ferment carbohydrates thermotolerantly. In contrast, $P$. mendocina disappeared in the acidogenesis process because of its mesophilicity. The most thermophiles detected as DGGE bands could grow catalyzing carbohydrates metabolism in swine wastewater to produce volatile fatty acids thermotolerantly [130]. The combination of molecular tools, such as DGGE, gene sequencing, and FISH, with microbial activity test seems to be essential for a better characterization of anaerobic biomass [130].

An excellent way to overcome some of the problems of studying microbial populations of a microcosm without resorting to traditional methodology is to use fluorescent probes. These are short sequences of DNA (16-20 nucleotides) labeled with a fluorescent dye. These sequences recognize 16S rRNA sequences in fixed cells and hybridize with them in situ (DNA-RNA matching) (Figure 4). The specificity of the probe enables detection/identification on any desired taxonomic level, from domain down to a resolution suitable for differentiating between individual species. The main shortcoming of this technique lies in the lack of availability of probes targeting the desired bacterial taxon or group. Although it is possible, in theory, to design the most apt probe for each application thanks to the growing rRNA sequence databases (16/18S and 23/28S rRNA), it may be impossible to develop a probe that specifically detects certain groups of microorganisms that share metabolic properties (e.g., sulfatereduction or halo-respiration). Furthermore, some previous knowledge of the expected microorganisms in the sample is often required to apply this method successfully. To target a particular species, a specific probe must be ready or its $16 \mathrm{~S}$ rRNA sequence must be available.

The study led by Stahl with pure cultures of methanogenic Archaea [141] formed the basis for all subsequent work in this area. In this pioneering study, many of the probes currently used to identify methanogenic microorganisms at different taxonomic levels (order, family, and genus) were described. The authors themselves used these probes to locate and quantify methanobacteria living in different anaerobic digesters [142]. Ever since the first studies on UASB reactors in the early 1980s, granular sludge has been popular with researchers from different fields of anaerobic digestion. Despite efforts and multiple articles, including guidelines for start-up of UASB reactors with granulation $[143,144]$ and mechanism and models $[145,146]$, the phenomenon of granulation is not well understood. Molecular techniques to analyze this form of biomass were introduced in the last decade and they have contributed greatly to the knowledge of its microbiology. After the pioneering work by [147] and the excellent contribution by [148] on the structure, composition, and distribution of different microbial groups, a number of aspects of this remarkable microcosm have been corroborated, disproved, and explained.

Publications that further illustrate the application of FISH in anaerobic digestion have dealt with the interaction and distribution of trophic groups, such as sulfate reducing bacteria and methanogenic Archaea in methanogenic/sulfidogenic reactors [149], or differentiation between hydrogenotrophic 
and acetoclastic methanobacteria, and within this group between Methanosaeta and Methanosarcina [150, 151]. The influence of feeding on granule structure and microbial composition has been also assessed by FISH [152]. Other works have emphasized the dependence of the settling behavior of UASB granules on their microbial composition and the decisive role of the positioning of methanogenic Archaea in granules during sedimentation or flotation [153]. A recent paper by 150 mentioned earlier when discussing the use of $16 \mathrm{~S}$ rDNA-sequencing for the identification of microorganisms deserves highlighting again, as it dealt with filamentous bacteria that cause sludge bulking in UASB reactors and the involvement of members of the Chloroflexi phylum in this phenomenon. The authors reported an in situ hybridization based survey of the distribution of these microorganisms in thermophilic, as well as mesophilic UASB sludge granules. The authors [154] operated UASB reactors for the treatment of ammonia rich landfill leachates and were able to corroborate the impact of high ammonia loads on the microbial community of the sludge granules with FISH. The same authors [56] in a subsequent work also with UASB reactors operated under high ammonia concentrations found that the differences in the efficiencies of reactors were correlated with the proportion of resistant and sensitive microorganisms dominated in the reactors.

The most recent approaches combine complementary techniques. The authors [152] have studied the microbial composition and structure of different types of granules in a UASB reactor that treated wastewater from a brewery. The authors used FISH, DGGE, cloning, and electron microscopy to gain insight into the structure, function, and physical appearance of methanogenic granules. The use of multiple techniques was necessary to elucidate the structure-function relationship of the different granules. The authors [155] studied in depth the microbial community of granules from a reactor treating paper mill wastewater with a similar approach. In situ hybridization has been also used as a molecular tool to describe microbial communities in other anaerobic wastewater treatment systems beside UASB reactors. A few noteworthy publications include Plumb's analysis of the microbial composition of the biomass inside an anaerobic baffled reactor $[155,156]$.

We will bring this section to a close with two final comments. First, we should remember that FISH is exclusively a taxonomic method that is most commonly used to examine whether members of a specific phylogenetic affiliation are present in a sample. It cannot, however, reveal information about the function or metabolic features of the microorganisms, although these characteristics can sometimes be deduced from comparison of the microorganisms detected with phylogenetically related bacteria. With a view to overcoming this limitation, [157] have presented an approach that combined FISH with microautoradiography using substrates labeled with $3 \mathrm{H}$ or $14 \mathrm{C}$. This combination allowed them to determine metabolic activities and simultaneously identify the microorganisms involved. This strategy can be useful for analyzing the structure and function of microbial communities, though it makes the technique much more complex.
The second closing remark refers to the quantitative aspects of FISH. The possibility of quantitative results represents a big advantage over the other molecular techniques, but this only applies to homogeneous and evenly distributed samples. The bacterial count per region of the microscopic grid should lie between 30 and 150 . Between 10 and 20 regions should be counted to ensure statistically significant cell counts. Nonideal samples and fluorescent background (a common phenomenon with environmental and sludge samples) can make cell counting by fluorescence microscopy a tedious and time consuming process that can be influenced by the judgment of the operator and his or her experience. Truth in this case is in the eye of the beholder, and a standardized and automatic procedure would be preferred. This is possible with a laser confocal microscope or an epifluorescence microscope coupled to a digital camera and a computer workstation to analyze the pictures. The system usually requires expensive software, which makes it less accessible, although free simple software can be found on the Internet (Image J, Image Pro Plus). Confocal microscopy on its own is of course already an extraordinarily powerful tool for examining the threedimensional structure and texture of the microbial aggregates (granules, biofilms) that develop in wastewater treatment systems [130].

Concurrent utilization of multiple molecular techniques is a common practice for studying microbial community structure, function, and dynamics. For example, a combination of FISH and microautoradiography (FISH-MAR), FISHSIP, and microarrays can be used to evaluate microbial structure and function. Figure 5 illustrates how different molecular techniques can be used to analyze microbial community structure, function, and metabolic transformation separately or together. FISH, DGGE, ribosomal inter-genic spacer analysis (RISA),T-RFLP, clone libraries, DGGE, and T-RFLP are the monitoring techniques that have been used most frequently for microbial community structure analysis, with DGGE and T-RFLP being the procedures most commonly used concurrently with other techniques. Several recent molecular techniques that have been used for microbial identification and detection microarray are few of the most advanced and sophisticated techniques.

\section{Conclusions}

Anaerobic digestion is a complicated reduction process involving a number of biochemical reactions under anaerobic conditions. This digestion processes convert biomass to energy, used in recycling of organic wastes and reduction of hazardous effects on the environment. Hydrolysis, acidogenesis, acetogenesis, and methanogenesis are different stages of anaerobic digestion. Biogas is possible due to the different groups of microorganisms, namely, fermentative, syntrophic, acetogenic, and methanogenic bacteria. Methanogens are the vital microbes and have decisive role for biomethane production and consist of hydrogenotrophic and acetotrophic and the substrates such as $\mathrm{CH}_{3} \mathrm{COOH}, \mathrm{H}_{2}$, and $\mathrm{CO}_{2}$. Methanogenesis occurs through two pathways: the direct cleavage of 


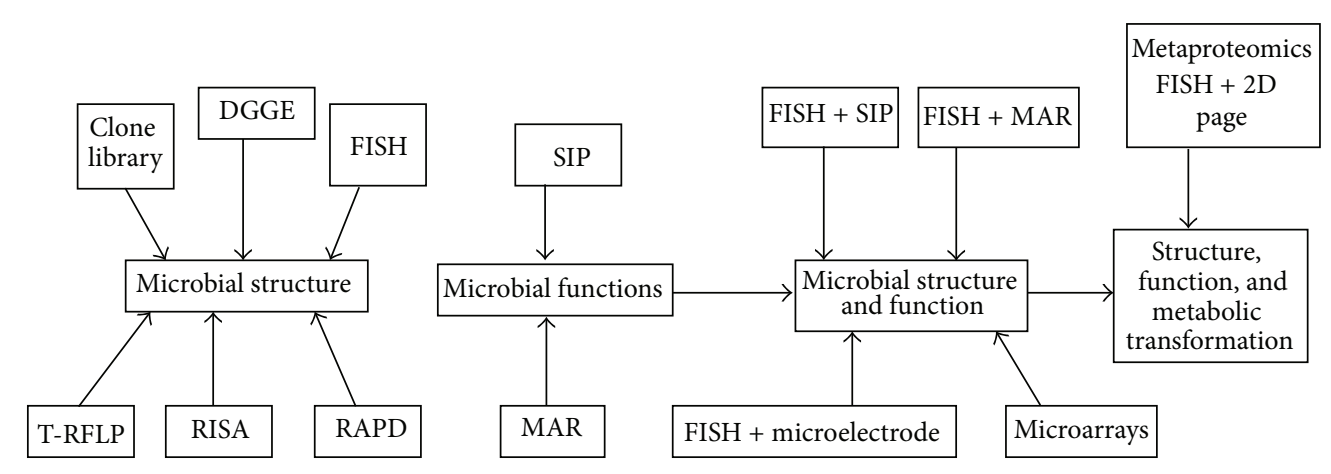

FIGURE 5: Conceptualization of the role of currently available molecular biology and postgenomic techniques for analysis of microbial community structure, function, and metabolic transformation [46].

acetate to $\mathrm{CH}_{4}$ and $\mathrm{CO}_{2}$ known as acetoclastic methanogenesis and hydrogenotrophic methanogenesis reducing the $\mathrm{CO}_{2}$ with hydrogen gas. The share of each pathway to the methanogenesis depends on the inoculum sludge, the organic substrate, and the process conditions.

Cellulose is the most abundant biopolymer on earth and is also a significant part of solid wastes. The cellulosic waste can be digested anaerobically to methane which is a main source of energy. Plant cell walls are relatively complex structures; a great variety of enzymes are needed for extensive enzymatic hydrolysis. Three cultivable species of ruminal bacteria (Ruminococcus albus, Ruminococcus flavefaciens, and Fibrobacter succinogenes) are found at high numbers in the rumen and are capable of rapid growth on cellulose.

Inocula play an important role in anaerobic reactor startup by balancing the populations of syntrobacter and methanogens. This balance makes syntrophic metabolism thermodynamically feasible in anaerobic digestion. The source of inocula not only affects the amount of biogas production but also influences the kinetics of the process of anaerobic digestion.

Different molecular techniques such as DGGE and FISH are being utilized for studying the microbial dynamic changes in the microbial communities for anaerobic digester. Microbial communities can be investigated with DGGE analysis. This method is one of the most widely used fingerprinting technique with the benefit of describing microbial communities by the recovery and sequencing of amplifications products. FISH is exclusively a taxonomic technique, that is, most commonly used to examine whether members of a specific phylogenetic affiliation are present in the sample. However, it cannot reveal information about the function or metabolic features of the microorganisms. The quantitative aspect of the FISH is an advantage while comparing it with other molecular techniques and it is applicable only to homogenous and evenly distributed samples. The present molecular techniques are a common practice for studying microbial community structure, function, and dynamics. Various combinations of FISH and microautoradiography (FISH-SIP), FISH-SIP and microarrays can be used to evaluate microbial structure and function.

\section{Conflict of Interests}

It is declared that the authors have neither any conflict of interests nor financial gain from this paper.

\section{References}

[1] S. N. Naik, V. V. Goud, P. K. Rout, and A. K. Dalai, "Production of first and second generation biofuels: a comprehensive review," Renewable and Sustainable Energy Reviews, vol. 14, no. 2, pp. 578-597, 2010.

[2] G. Lyberatos and I. Skiadas, "Modelling of anaerobic digestion: a review," GlobalNEST International Journal, vol. 1, no. 2, pp. 6376, 1999.

[3] D. R. Boone, D. P. Chynoweth, R. A. Mah, P. H. Smith, and A. C. Wilkie, "Ecology and microbiology of biogasification," Biomass and Bioenergy, vol. 5, no. 3-4, pp. 191-202, 1993.

[4] J. Mata-Alvarez, S. Macé, and P. Llabrés, "Anaerobic digestion of organic solid wastes. An overview of research achievements and perspectives," Bioresource Technology, vol. 74, no. 1, pp. 3$16,2000$.

[5] D. de Graaf and R. Fendler, "Biogas production in Germany," SPIN Background Paper, 2010.

[6] P. Weiland, "Biogas production: current state and perspectives," Applied Microbiology and Biotechnology, vol. 85, no. 4, pp. 849860, 2010.

[7] K. Ziemiński and M. Frąc, "Methane fermentation process as anaerobic digestion of biomass: transformations, stages and microorganisms," African Journal of Biotechnology, vol. 11, no. 18, pp. 4127-4139, 2012.

[8] P. A. M. Claassen, A. M. Lopez Contreras, L. Sijtsma et al., "Utilisation of biomass for the supply of energy carriers," Applied Microbiology and Biotechnology, vol. 52, no. 6, pp. 741755, 1999.

[9] F. A. M. de Bok, H. J. M. Harmsen, C. M. Plugge et al., “The first true obligately syntrophic propionate-oxidizing bacterium, Pelotomaculum schinkii sp. nov., co-cultured with Methanospirillum hungatei, and emended description of the genus Pelotomaculum," International Journal of Systematic and Evolutionary Microbiology, vol. 55, no. 4, pp. 1697-1703, 2005.

[10] I. M. Arbon, "Worldwide use of biomass in power generation and combined heat and power schemes," Proceedings of the Institution of Mechanical Engineers A, vol. 216, no. 1, pp. 41-58, 2002. 
[11] B. Demirel and P. Scherer, "The roles of acetotrophic and hydrogenotrophic methanogens during anaerobic conversion of biomass to methane: a review," Reviews in Environmental Science and Biotechnology, vol. 7, no. 2, pp. 173-190, 2008.

[12] K. H. Nealson, "Sediment bacteria: who's there, what are they doing, and what's new?" Annual Review of Earth and Planetary Sciences, vol. 25, pp. 403-434, 1997.

[13] R. Conrad, "Contribution of hydrogen to methane production and control of hydrogen concentrations in methanogenic soils and sediments," FEMS Microbiology Ecology, vol. 28, no. 3, pp. 193-202, 1999.

[14] W. Parawira, J. S. Read, B. Mattiasson, and L. Björnsson, "Energy production from agricultural residues: high methane yields in pilot-scale two-stage anaerobic digestion," Biomass and Bioenergy, vol. 32, no. 1, pp. 44-50, 2008.

[15] M. Bryant, "Microbial methane production: theoretical aspects," Journal of Animal Science, vol. 48, no. 1, pp. 193-201, 1979.

[16] P. Smith, "The microbial ecology of sludge methanogenesis," Developments in Industrial Microbiology, vol. 7, pp. 156-161, 1966.

[17] I. Ntaikou, G. Antonopoulou, and G. Lyberatos, "Biohydrogen production from biomass and wastes via dark fermentation: a review," Waste and Biomass Valorization, vol. 1, no. 1, pp. 21-39, 2010.

[18] B. Schink, "Energetics of syntrophic cooperation in methanogenic degradation," Microbiology and Molecular Biology Reviews, vol. 61, no. 2, pp. 262-280, 1997.

[19] W. Verstraete, F. Doulami, E. Volcke, M. Tavernier, H. Nollet, and J. Roles, "The importance of anaerobic digestion for global environmental development," in Proceedings of the JSCE Annual Meeting, pp. 97-102, 2002.

[20] M. E. Griffin, K. D. McMahon, R. I. Mackie, and L. Raskin, "Methanogenic population dynamics during start-up of anaerobic digesters treating municipal solid waste and biosolids," Biotechnology and Bioengineering, vol. 57, no. 3, pp. 342-355, 1998.

[21] D. Karakashev, D. J. Batstone, and I. Angelidaki, "Influence of environmental conditions on methanogenic compositions in anaerobic biogas reactors," Applied and Environmental Microbiology, vol. 71, no. 1, pp. 331-338, 2005.

[22] K. D. McMahon, D. Zheng, A. J. M. Stams, R. I. Mackie, and L. Raskin, "Microbial population dynamics during start-up and overload conditions of anaerobic digesters treating municipal solid waste and sewage sludge," Biotechnology and Bioengineering, vol. 87, no. 7, pp. 823-834, 2004.

[23] F. Raposo, V. Fernández-Cegrí, M. De la Rubia et al., "Biochemical methane potential (BMP) of solid organic substrates: evaluation of anaerobic biodegradability using data from an international interlaboratory study," Journal of Chemical Technology and Biotechnology, vol. 86, no. 8, pp. 1088-1098, 2011.

[24] F. Xu, J. Shi, W. Lv, Z. Yu, and Y. Li, "Comparison of different liquid anaerobic digestion effluents as inocula and nitrogen sources for solid-state batch anaerobic digestion of corn stover," Waste Managementment, vol. 33, pp. 26-32, 2013.

[25] I. Angelidaki, M. Alves, D. Bolzonella et al., "Defining the biomethane potential (BMP) of solid organic wastes and energy crops: a proposed protocol for batch assays," Water Science and Technology, vol. 59, no. 5, pp. 927-934, 2009.

[26] P. D. Jensen, M. T. Hardin, and W. P. Clarke, "Effect of biomass concentration and inoculum source on the rate of anaerobic cellulose solubilization," Bioresource Technology, vol. 100, no. 21, pp. 5219-5225, 2009.
[27] C. Eskicioglu and M. Ghorbani, "Effect of inoculum/substrate ratio on mesophilic anaerobic digestion of bioethanol plant whole stillage in batch mode," Process Biochemistry, vol. 46, no. 8, pp. 1682-1687, 2011.

[28] F. Xu, J. Shi, W. Lv, Z. Yu, and Y. Li, "Comparison of different liquid anaerobic digestion effluents as inocula and nitrogen sources for solid state anaerobic digestion of corn stover," Waste Management, vol. 33, pp. 26-32, 2012.

[29] G. Esposito, L. Frunzo, F. Liotta, A. Panico, and F. Pirozzi, "Biomethane potential tests to measure the biogas production from the digestion and co-digestion of complex organic substrates," Open Environmental Engineering Journal, vol. 5, pp. 1-8, 2012.

[30] C. González-Fernández and P. A. García-Encina, "Impact of substrate to inoculum ratio in anaerobic digestion of swine slurry," Biomass and Bioenergy, vol. 33, no. 8, pp. 1065-1069, 2009.

[31] F. Di Maria, A. Sordi, and C. Micale, "Optimization of solid state anaerobic digestion by inoculum recirculation: the case of an existing mechanical biological treatment plant," Applied Energy, vol. 97, pp. 462-469, 2012.

[32] F. Lü, L. Hao, M. Zhu, L. Shao, and P. He, "Initiating methanogenesis of vegetable waste at low inoculum-to-substrate ratio: importance of spatial separation," Bioresource Technology, vol. 105, pp. 169-173, 2012.

[33] S. Suwannoppadol, G. Ho, and R. Cord-Ruwisch, "Rapid startup of thermophilic anaerobic digestion with the turf fraction of MSW as inoculum," Bioresource Technology, vol. 102, no. 17, pp. 7762-7767, 2011.

[34] J. G. Zeikus, “The biology of methanogenic bacteria," Bacteriological Reviews, vol. 41, no. 2, pp. 514-541, 1977.

[35] Y. Yang, Z. Zhang, J. Lu, and T. Maekawa, "Continuous methane fermentation and the production of vitamin B 12 in a fixed-bed reactor packed with loofah," Bioresource Technology, vol. 92, no. 3, pp. 285-290, 2004.

[36] P. M. Vignais, B. Billoud, and J. Meyer, "Classification and phylogeny of hydrogenases," FEMS Microbiology Reviews, vol. 25, no. 4, pp. 455-501, 2001.

[37] T. Watanabe, S. Asakawa, A. Nakamura, K. Nagaoka, and M. Kimura, "DGGE method for analyzing $16 \mathrm{~S}$ rDNA of methanogenic archaeal community in paddy field soil," FEMS Microbiology Letters, vol. 232, no. 2, pp. 153-163, 2004.

[38] B. K. Ahring, A. A. Ibrahim, and Z. Mladenovska, "Effect of temperature increase from 55 to $65^{\circ} \mathrm{C}$ on performance and microbial population dynamics of an anaerobic reactor treating cattle manure," Water Research, vol. 35, no. 10, pp. 2446-2452, 2001.

[39] H. Bouallagui, M. Torrijos, J. J. Godon et al., "Microbial monitoring by molecular tools of a two-phase anaerobic bioreactor treating fruit and vegetable wastes," Biotechnology Letters, vol. 26, no. 10, pp. 857-862, 2004.

[40] V. K. Ilyin, I. N. Korniushenkova, L. V. Starkova, and K. S. Lauriniavichius, "Study of methanogenesis during bioutilization of plant residuals," Acta Astronautica, vol. 56, no. 4, pp. 465-470, 2005.

[41] M. H. Gerardi, The Microbiology of Anaerobic Digesters, WileyInterscience, 2003.

[42] J. De Vrieze, T. Hennebel, N. Boon, and W. Verstraete, "Methanosarcina: the rediscovered methanogen for heavy duty biomethanation," Bioresource Technology, vol. 112, pp. 1-9, 2012. 
[43] A. Schnürer, B. Schink, and B. H. Svensson, "Clostridium ultunense sp. nov., a mesophilic bacterium oxidizing acetate in syntrophic association with a hydrogenotrophic methanogenic bacterium," International Journal of Systematic Bacteriology, vol. 46, no. 4, pp. 1145-1152, 1996.

[44] M. Goberna, M. Gadermaier, C. García, B. Wett, and H. Insam, "Adaptation of methanogenic communities to the cofermentation of cattle excreta and olive mill wastes at $37^{\circ} \mathrm{C}$ and $55^{\circ} \mathrm{C}$," Applied and Environmental Microbiology, vol. 76, no. 19, pp. 6564-6571, 2010.

[45] P. J. Weimer, J. B. Russell, and R. E. Muck, "Lessons from the cow: what the ruminant animal can teach us about consolidated bioprocessing of cellulosic biomass," Bioresource Technology, vol. 100, no. 21, pp. 5323-5331, 2009.

[46] S. Khanal, Anaerobic Biotechnology for Bioenergy Production: Principles and Applications, Wiley-Blackwell, 2009.

[47] Y. Chen, J. J. Cheng, and K. S. Creamer, "Inhibition of anaerobic digestion process: a review," Bioresource Technology, vol. 99, no. 10, pp. 4044-4064, 2008.

[48] J. Ma, L. J. Mungoni, W. Verstraete, and M. Carballa, "Maximum removal rate of propionic acid as a sole carbon source in UASB reactors and the importance of the macro- and micro-nutrients stimulation," Bioresource Technology, vol. 100, no. 14, pp. 34773482, 2009.

[49] K. C. Wijekoon, C. Visvanathan, and A. Abeynayaka, "Effect of organic loading rate on VFA production, organic matter removal and microbial activity of a two-stage thermophilic anaerobic membrane bioreactor," Bioresource Technology, vol. 102, no. 9, pp. 5353-5360, 2011.

[50] W. Gujer and A. J. B. Zehnder, "Conversion processes in anaerobic digestion," Water Science and Technology, vol. 15, no. 8-9, pp. 127-167, 1983.

[51] L. Appels, J. Baeyens, J. Degrève, and R. Dewil, "Principles and potential of the anaerobic digestion of waste-activated sludge," Progress in Energy and Combustion Science, vol. 34, no. 6, pp. 755-781, 2008.

[52] A. Conklin, H. D. Stensel, and J. Ferguson, "Growth kinetics and competition between methanosarcina and Methanosaeta in Mesophilic anaerobic digestion," Water Environment Research, vol. 78, no. 5, pp. 486-496, 2006.

[53] Y. Liu, Y. Zhang, X. Quan, J. Zhang, H. Zhao, and S. Chen, "Effects of an electric field and zero valent iron on anaerobic treatment of azo dye wastewater and microbial community structures," Bioresource Technology, vol. 102, no. 3, pp. 25782584, 2011.

[54] S. G. Shin, B. W. Zhou, S. Lee, W. Kim, and S. Hwang, "Variations in methanogenic population structure under overloading of pre-acidified high-strength organic wastewaters," Process Biochemistry, vol. 46, no. 4, pp. 1035-1038, 2011.

[55] R. K. Thauer, A.-K. Kaster, H. Seedorf, W. Buckel, and R. Hedderich, "Methanogenic archaea: ecologically relevant differences in energy conservation," Nature Reviews Microbiology, vol. 6, no. 8, pp. 579-591, 2008.

[56] B. Calli, B. Mertoglu, B. Inanc, and O. Yenigun, "Community changes during star-up in methanogenic bioreactors exposed to increasing levels of ammonia," Environmental Technology, vol. 26, no. 1, pp. 85-91, 2005.

[57] A. Schnürer and Å. Nordberg, "Ammonia, a selective agent for methane production by syntrophic acetate oxidation at mesophilic temperature," Water Science and Technology, vol. 57, no. 5, pp. 735-740, 2008.
[58] X. Qu, V. A. Vavilin, L. Mazéas et al., "Anaerobic biodegradation of cellulosic material: batch experiments and modelling based on isotopic data and focusing on aceticlastic and nonaceticlastic methanogenesis," Waste Management, vol. 29, no. 6, pp. 1828-1837, 2009.

[59] Y. Yu, J. Kim, and S. Hwang, "Use of real-time PCR for groupspecific quantification of aceticlastic methanogens in anaerobic processes: population dynamics and community structures," Biotechnology and Bioengineering, vol. 93, no. 3, pp. 424-433, 2006.

[60] A. Briones and L. Raskin, "Diversity and dynamics of microbial communities in engineered environments and their implications for process stability," Current Opinion in Biotechnology, vol. 14, no. 3, pp. 270-276, 2003.

[61] E. Nettmann, I. Bergmann, S. Pramschüfer et al., "Polyphasic analyses of methanogenic archaeal communities in agricultural biogas plants," Applied and Environmental Microbiology, vol. 76, no. 8, pp. 2540-2548, 2010.

[62] J. G. Ferry, "Enzymology of one-carbon metabolism in methanogenic pathways," FEMS Microbiology Reviews, vol. 23, no. 1, pp. 13-38, 1999.

[63] J. Shi, Z. Wang, J. A. Stiverson, Z. Yu, and Y. Li, "Reactor performance and microbial community dynamics during solidstate anaerobic digestion of Corn stover at mesophilic and thermophilic conditions," Bioresource Technology, vol. 136, pp. 574-581, 2013.

[64] Y. Liu, D. R. Boone, R. Sleat, and R. A. Mah, "Methanosarcina mazei LYC, a new methanogenic isolate which produces a disaggregating enzyme," Applied and Environmental Microbiology, vol. 49, no. 3, pp. 608-613, 1985.

[65] R. Spanheimer and V. Müller, "The molecular basis of salt adaptation in Methanosarcina mazei Göl," Archives of Microbiology, vol. 190, no. 3, pp. 271-279, 2008.

[66] B. F. Staley, F. L. de los Reyes III, and M. A. Barlaz, "Effect of spatial differences in microbial activity, $\mathrm{pH}$, and substrate levels on methanogenesis initiation in refuse," Applied and Environmental Microbiology, vol. 77, no. 7, pp. 2381-2391, 2011.

[67] S. Hattori, "Syntrophic acetate-oxidizing microbes in methanogenic environments," Microbes and Environments, vol. 23, no. 2, pp. 118-127, 2008.

[68] T. Shigematsu, Y. Tang, H. Kawaguchi et al., "Effect of dilution rate on structure of a mesophilic acetate-degrading methanogenic community during continuous cultivation," Journal of Bioscience and Bioengineering, vol. 96, no. 6, pp. 547-558, 2003.

[69] M. Westerholm, S. Roos, and A. Schnürer, "Syntrophaceticus schinkiigen. nov., sp. nov., an anaerobic, syntrophic acetateoxidizing bacterium isolated from a mesophilic anaerobic filter," FEMS Microbiology Letters, vol. 309, no. 1, pp. 100-104, 2010.

[70] D. Sasaki, T. Hori, S. Haruta, Y. Ueno, M. Ishii, and Y. Igarashi, "Methanogenic pathway and community structure in a thermophilic anaerobic digestion process of organic solid waste," Journal of Bioscience and Bioengineering, vol. 111, no. 1, pp. 41-46, 2011.

[71] L.-P. Hao, F. Lü, P.-J. He, L. Li, and L.-M. Shao, "Predominant contribution of syntrophic acetate oxidation to thermophilic methane formation at high acetate concentrations," Environmental Science and Technology, vol. 45, no. 2, pp. 508-513, 2011.

[72] D. R. Lovley, "Reach out and touch someone: potential impact of DIET (direct interspecies energy transfer) on anaerobic biogeochemistry, bioremediation, and bioenergy," Reviews in Environmental Science and Biotechnology, vol. 10, no. 2, pp. 101105, 2011. 
[73] M. Morita, N. S. Malvankar, A. E. Franks et al., "Potential for direct interspecies electron transfer in methanogenic wastewater digester aggregates," mBio, vol. 2, no. 4, Article ID e00159-11, 2011.

[74] D. R. Francoleon, P. Boontheung, Y. Yang et al., "S-layer, surface-accessible, and concanavalin a binding proteins of Methanosarcina acetivorans and methanosarcina mazei," Journal of Proteome Research, vol. 8, no. 4, pp. 1972-1982, 2009.

[75] A. Bhadra, J. M. Scharer, and M. Moo-Young, "Anaerobic digestion of native cellulosic wastes," MIRCEN Journal of Applied Microbiology and Biotechnology, vol. 2, no. 3, pp. 349-358, 1986.

[76] Y.-H. P. Zhang and L. R. Lynd, "Cellulose utilization by Clostridium thermocellum: bioenergetics and hydrolysis product assimilation," Proceedings of the National Academy of Sciences of the United States of America, vol. 102, no. 20, pp. 7321-7325, 2005.

[77] T. Noike, G. Endo, and J.-E. Chang, "Characteristics of carbohydrate degradation and the rate-limiting step in anaerobic digestion," Biotechnology and Bioengineering, vol. 27, no. 10, pp. 1482-1489, 1985.

[78] L. R. Lynd, P. J. Weimer, W. H. Van Zyl, and I. S. Pretorius, "Microbial cellulose utilization: fundamentals and biotechnology," Microbiology and Molecular Biology Reviews, vol. 66, no. 3, pp. 506-577, 2002.

[79] A. P. Sinitsyn, A. V. Gusakov, and E. Y. Vlasenko, "Effect of structural and physico-chemical features of cellulosic substrates on the efficiency of enzymatic hydrolysis," Applied Biochemistry and Biotechnology, vol. 30, no. 1, pp. 43-59, 1991.

[80] H. Song, W. P. Clarke, and L. L. Blackall, "Concurrent microscopic observations and activity measurements of cellulose hydrolyzing and methanogenic populations during the batch anaerobic digestion of crystalline cellulose," Biotechnology and Bioengineering, vol. 91, no. 3, pp. 369-378, 2005.

[81] P. J. Weimer, J. M. Lopez-Guisa, and A. D. French, "Effect of cellulose fine structure on kinetics of its digestion by mixed ruminal microorganisms in vitro," Applied and Environmental Microbiology, vol. 56, no. 8, pp. 2421-2429, 1990.

[82] Y. Lu, Y.-H. P. Zhang, and L. R. Lynd, "Enzyme-microbe synergy during cellulose hydrolysis by Clostridium thermocellum," Proceedings of the National Academy of Sciences of the United States of America, vol. 103, no. 44, pp. 16165-16169, 2006.

[83] W. H. Schwarz, "The cellulosome and cellulose degradation by anaerobic bacteria," Applied Microbiology and Biotechnology, vol. 56, no. 5-6, pp. 634-649, 2001.

[84] C. A. O’Sullivan, P. C. Burrell, W. P. Clarke, and L. L. Blackall, "Comparison of cellulose solubilisation rates in rumen and landfill leachate inoculated reactors," Bioresource Technology, vol. 97, no. 18, pp. 2356-2363, 2006.

[85] K. Golkowska and M. Greger, "Thermophilic digestion of cellulose at high-organic loading rates," Engineering in Life Sciences, vol. 10, no. 6, pp. 600-606, 2010.

[86] R. E. Hungate, Rumen and Its Microbes, Academic Press, New York, NY, USA, 1966.

[87] S.-Y. Ding, M. T. Rincon, R. Lamed et al., "Cellulosomal scaffoldin-like proteins from Ruminococcus flavefaciens," Journal of Bacteriology, vol. 183, no. 6, pp. 1945-1953, 2001.

[88] M. Qi, K. E. Nelson, S. C. Daugherty et al., "Novel molecular features of the fibrolytic intestinal bacterium Fibrobacter intestinalis not shared with Fibrobacter succinogenes as determined by suppressive subtractive hybridization," Journal of Bacteriology, vol. 187, no. 11, pp. 3739-3751, 2005.

[89] P. J. van Soest, Nutritional Ecology of the Ruminant, Comstock Publisher Association, 1994.
[90] A. Stephen, "Other plant polysaccharides," The Polysaccharides, vol. 2, article 97, 1983.

[91] K. Mengel and E. A. Kirkby, Principles of Plant Nutrition, Springer, 2001.

[92] R. I. Mackie, "Mutualistic fermentative digestion in the gastrointestinal tract: diversity and evolution," Integrative and Comparative Biology, vol. 42, no. 2, pp. 319-326, 2002.

[93] E. Annison, M. I. Chalmers, S. Marshall, and R. Synge, "Ruminal ammonia formation in relation to the protein requirement of sheep: III. Ruminal ammonia formation with various diets," Journal of Agricultural Science, vol. 44, no. 03, pp. 270-273, 1954.

[94] K. El-Shazly, "Degradation of protein in the rumen of the sheep. I. Some volatile fatty acids, including branched-chain isomers, found in vivo," The Biochemical journal, vol. 51, no. 5, pp. 640647, 1952.

[95] M. A. Cotta, "Utilization of nucleic acids by Selenomonas ruminantium and other ruminal bacteria," Applied and Environmental Microbiology, vol. 56, no. 12, pp. 3867-3870, 1990.

[96] R. I. Mackie, B. A. White, and M. P. Bryant, "Lipid metabolism in anaerobic ecosystems," Critical Reviews in Microbiology, vol. 17, no. 6, pp. 449-479, 1991.

[97] J. Pérez, J. Muñoz-Dorado, T. de La Rubia, and J. Martínez, "Biodegradation and biological treatments of cellulose, hemicellulose and lignin: an overview," International Microbiology, vol. 5, no. 2, pp. 53-63, 2002.

[98] C. Sánchez, "Lignocellulosic residues: biodegradation and bioconversion by fungi," Biotechnology Advances, vol. 27, no. 2, pp. 185-194, 2009.

[99] G. Cplj, G. Daigger, and H. Lim, Biological Wastewater Treatment, Marcel Dekker, 1999.

[100] B. Malik, M. Bo, and S. Bo, Evaluation of Process Parameters and Treatments of Different Raw Materials for Biogas Production, Lund University, 2012.

[101] L. Li, X. Yang, X. Li, M. Zheng, J. Chen, and Z. Zhang, "The influence of inoculum sources on anaerobic biogasification of $\mathrm{NaOH}$-treated corn stover," Energy Sources A, vol. 33, no. 2, pp. 138-144, 2011.

[102] L. Neves, R. Oliveira, and M. M. Alves, "Influence of inoculum activity on the bio-methanization of a kitchen waste under different waste/inoculum ratios," Process Biochemistry, vol. 39, no. 12, pp. 2019-2024, 2004.

[103] W. S. Lopes, V. D. Leite, and S. Prasad, "Influence of inoculum on performance of anaerobic reactors for treating municipal solid waste," Bioresource Technology, vol. 94, no. 3, pp. 261-266, 2004.

[104] C. Sans, J. Mata-Alvarez, F. Cecchi, P. Pavan, and A. Bassetti, "Acidogenic fermentation of organic urban wastes in a plugflow reactor under thermophilic conditions," Bioresource Technology, vol. 54, no. 2, pp. 105-110, 1995.

[105] D. Obaja, S. Macé, J. Costa, C. Sans, and J. Mata-Alvarez, "Nitrification, denitrification and biological phosphorus removal in piggery wastewater using a sequencing batch reactor," Bioresource Technology, vol. 87, no. 1, pp. 103-111, 2003.

[106] T. Forster-Carneiro, M. Pérez, L. I. Romero, and D. Sales, "Drythermophilic anaerobic digestion of organic fraction of the municipal solid waste: focusing on the inoculum sources," Bioresource Technology, vol. 98, no. 17, pp. 3195-3203, 2007.

[107] P. K. Pandey, P. M. Ndegwa, M. L. Soupir, J. R. Alldredge, and M. J. Pitts, "Efficacies of inocula on the startup of anaerobic reactors treating dairy manure under stirred and unstirred conditions," Biomass and Bioenergy, vol. 35, no. 7, pp. 2705-2720, 2011. 
[108] A. Nopharatana, W. P. Clarke, P. C. Pullammanappallil, P. Silvey, and D. P. Chynoweth, "Evaluation of methanogenic activities during anaerobic digestion of municipal solid waste," Bioresource Technology, vol. 64, no. 3, pp. 169-174, 1998.

[109] G. K. Anderson, B. Kasapgil, and O. Ince, "Microbiological study of two-stage anaerobic digestion during start-up," Water Research, vol. 28, no. 11, pp. 2383-2392, 1994.

[110] S. P. Barnes and J. Keller, "Cellulosic waste degradation by rumen-enhanced anaerobic digestion," Water Science and Technology, vol. 48, no. 4, pp. 155-162, 2003.

[111] P. C. Burrell, C. O'Sullivan, H. Song, W. P. Clarke, and L. L. Blackall, "Identification, detection, and spatial resolution of Clostridium populations responsible for cellulose degradation in a methanogenic landfill leachate bioreactor," Applied and Environmental Microbiology, vol. 70, no. 4, pp. 2414-2419, 2004.

[112] M. W. Fields, S. Mallik, and J. B. Russell, "Fibrobacter succinogenes S85 ferments ball-milled cellulose as fast as cellobiose until cellulose surface area is limiting," Applied Microbiology and Biotechnology, vol. 54, no. 4, pp. 570-574, 2000.

[113] H. J. Gijzen, H. J. Lubberding, M. J. T. Gerhardus, and G. D. Vogels, "Contribution of rumen protozoa to fibre degradation and cellulase activity in vitro," FEMS Microbiology Letters, vol. 53, no. 1, pp. 35-43, 1988.

[114] Z.-H. Hu, G. Wang, and H.-Q. Yu, "Anaerobic degradation of cellulose by rumen microorganisms at various $\mathrm{pH}$ values," Biochemical Engineering Journal, vol. 21, no. 1, pp. 59-62, 2004.

[115] V. Kostyukovsky, T. Inamoto, T. Ando, Y. Nakai, and K. Ogimoto, "Degradation of hay by rumen fungi in artificial rumen (RUSITEC)," Journal of General and Applied Microbiology, vol. 41, no. 1, pp. 83-86, 1995.

[116] T. L. Miller, E. Currenti, and M. J. Wolin, "Anaerobic bioconversion of cellulose by Ruminococcus albus, Methanobrevibacter smithii, and Methanosarcina barkeri," Applied Microbiology and Biotechnology, vol. 54, no. 4, pp. 494-498, 2000.

[117] W. D. Murray, "Effects of cellobiose and glucose on cellulose hydrolysis by both growing and resting cells of Bacteroides cellulosolvens," Biotechnology and Bioengineering, vol. 29, no. 9, pp. 1151-1154, 1987.

[118] R. Tammali, G. Seenayya, and G. Reddy, "Fermentation of cellulose to acetic acid by Clostridium lentocellum SG6: induction of sporulation and effect of buffering agent on acetic acid production," Letters in Applied Microbiology, vol. 37, no. 4, pp. 304-308, 2003.

[119] J. Chen and P. J. Weimer, "Competition among three predominant ruminal cellulolytic bacteria in the absence or presence of non-cellulolytic bacteria," Microbiology, vol. 147, no. 1, pp. 21-30, 2001.

[120] G. Coleman, A. Taylor, and J. Baker, "Rumen entodiniomorphid protozoa," in In Vitro Methods for Parasite Cultivation, A. E. R. Taylor and J. R. Baker, Eds., pp. 29-51, Academic Press, London, UK, 1987.

[121] T. L. Miller and M. J. Wolin, "Bioconversion of cellulose to acetate with pure cultures of Ruminococcus albus and a hydrogen-using acetogen," Applied and Environmental Microbiology, vol. 61, no. 11, pp. 3832-3835, 1995.

[122] P. J. Weimer and C. L. Odt, Cellulose Degradation by Ruminal Microbes: Physiological and Hydrolytic Diversity among Ruminal Cellulolytic Bacteria, vol. 618 of ACS Symposium Series, ACS Publications, 1995.

[123] M. I. van Dyke and A. J. McCarthy, "Molecular biological detection and characterization of Clostridium populations in municipal landfill sites," Applied and Environmental Microbiology, vol. 68, no. 4, pp. 2049-2053, 2002.

[124] S. Suwannoppadol, G. Ho, and R. Cord-Ruwisch, "Distribution of methanogenic potential in fractions of turf grass used as inoculum for the start-up of thermophilic anaerobic digestion," Bioresource Technology, vol. 117, no. 17, pp. 124-130, 2012.

[125] G. P. B. Marquez, W. T. Reichardt, R. V. Azanza, M. Klocke, and M. N. E. Montaño, "Thalassic biogas production from sea wrack biomass using different microbial seeds: cow manure, marine sediment and sea wrack-associated microflora," Bioresource Technology, vol. 133, pp. 612-617, 2013.

[126] T. Forster-Carneiro, M. Pérez, and L. I. Romero, "Influence of total solid and inoculum contents on performance of anaerobic reactors treating food waste," Bioresource Technology, vol. 99, no. 15, pp. 6994-7002, 2008.

[127] E. Elbeshbishy, G. Nakhla, and H. Hafez, "Biochemical methane potential (BMP) of food waste and primary sludge: influence of inoculum pre-incubation and inoculum source," Bioresource Technology, vol. 110, pp. 18-25, 2012.

[128] G. K. Kafle, S. H. Kim, and K. I. Sung, "Ensiling of fish industry waste for biogas production: a lab scale evaluation of biochemical methane potential (BMP) and kinetics," Bioresource Technology, vol. 127, pp. 326-336, 2012.

[129] L. Yan, Y. Gao, Y. Wang et al., "Diversity of a mesophilic lignocellulolytic microbial consortium which is useful for enhancement of biogas production," Bioresource Technology, vol. 111, pp. 49$54,2012$.

[130] L. Regueiro, P. Veiga, M. Figueroa et al., "Relationship between microbial activity and microbial community structure in six full-scale anaerobic digesters," Microbiological Research, vol. 167, no. 10, pp. 581-589, 2012.

[131] Q. Zhang, J. He, M. Tian et al., "Enhancement of methane production from cassava residues by biological pretreatment using a constructed microbial consortium," Bioresource Technology, vol. 102, no. 19, pp. 8899-8906, 2011.

[132] J. L. Sanz and T. Köchling, "Molecular biology techniques used in wastewater treatment: an overview," Process Biochemistry, vol. 42, no. 2, pp. 119-133, 2007.

[133] T. M. Lapara, C. H. Nakatsu, L. Pantea, and J. E. Alleman, "Phylogenetic analysis of bacterial communities in mesophilic and thermophilic bioreactors treating pharmaceutical wastewater," Applied and Environmental Microbiology, vol. 66, no. 9, pp. 3951-3959, 2000.

[134] P. Silvey, P. C. Pullammanappallil, L. Blackall, and P. Nichols, "Microbial ecology of the leach bed anaerobic digestion of unsorted municipal solid waste," Water Science and Technology, vol. 41, no. 3, pp. 9-16, 2000.

[135] T. Nakagawa, S. Sato, Y. Yamamoto, and M. Fukui, "Successive changes in community structure of an ethylbenzene-degrading sulfate-reducing consortium," Water Research, vol. 36, no. 11, pp. 2813-2823, 2002.

[136] Y. Ueno, S. Haruta, M. Ishii, and Y. Igarashi, "Changes in product formation and bacterial community by dilution rate on carbohydrate fermentation by methanogenic microflora in continuous flow stirred tank reactor," Applied Microbiology and Biotechnology, vol. 57, no. 1-2, pp. 65-73, 2001.

[137] M. A. Pereira, K. Roest, A. J. M. Stams, M. Mota, M. Alves, and A. D. L. Akkermans, "Molecular monitoring of microbial diversity in expanded granular sludge bed (EGSB) reactors treating oleic acid," FEMS Microbiology Ecology, vol. 41, no. 2, pp. 95-103, 2002. 
[138] T. Narihiro, T. Abe, Y. Yamanaka, and A. Hiraishi, "Microbial population dynamics during fed-batch operation of commercially available garbage composters," Applied Microbiology and Biotechnology, vol. 65, no. 4, pp. 488-495, 2004.

[139] C. Delbès, R. Moletta, and J.-J. Godon, "Bacterial and archaeal $16 \mathrm{~S}$ rDNA and 16S rRNA dynamics during an acetate crisis in an anaerobic digestor ecosystem," FEMS Microbiology Ecology, vol. 35, no. 1, pp. 19-26, 2001.

[140] T. P. Curtis and N. G. Craine, "The comparison of the diversity of activated sludge plants," Water Science and Technology, vol. 37, no. 4-5, pp. 71-78, 1998.

[141] L. Raskin, L. K. Poulsen, D. R. Noguera, B. E. Rittmann, and D. A. Stahl, "Quantification of methanogenic groups in anaerobic biological reactors by oligonucleotide probe hybridization," Applied and Environmental Microbiology, vol. 60, no. 4, pp. 12411248, 1994.

[142] L. Raskin, J. M. Stromley, B. E. Rittmann, and D. A. Stahl, "Group-specific 16S rRNA hybridization probes to describe natural communities of methanogens," Applied and Environmental Microbiology, vol. 60, no. 4, pp. 1232-1240, 1994.

[143] P. L. Hulshoff, The Phenomenon of Granulation of Anaerobic Sludge, Landbouwuniversiteit te Wageningen, 1989.

[144] L. W. Hulshoff Pol, S. I. de Castro Lopes, G. Lettinga, and P. N. L. Lens, "Anaerobic sludge granulation," Water Research, vol. 38, no. 6, pp. 1376-1389, 2004.

[145] Y. Liu, H.-L. Xu, S.-F. Yang, and J.-H. Tay, "Mechanisms and models for anaerobic granulation in upflow anaerobic sludge blanket reactor," Water Research, vol. 37, no. 3, pp. 661-673, 2003.

[146] J. E. Schmidt and B. K. Ahring, "Granular sludge formation in upflow anaerobic sludge blanket (UASB) reactors," Biotechnology and Bioengineering, vol. 49, pp. 229-246, 1996.

[147] H. J. M. Harmsen, H. M. P. Kengen, A. D. L. Akkermans, A. J. M. Stams, and W. M. De Vos, "Detection and localization of syntrophic propionate-oxidizing bacteria in granular sludge by in situ hybridization using 16S rRNA-based oligonucleotide probes," Applied and Environmental Microbiology, vol. 62, no. 5, pp. 1656-1663, 1996.

[148] Y. Sekiguchi, Y. Kamagata, K. Nakamura, A. Ohashi, and H. Harada, "Fluorescence in situ hybridization using 16S rRNAtargeted oligonucleotides reveals localization of methanogens and selected uncultured bacteria in mesophilic and thermophilic sludge granules," Applied and Environmental Microbiology, vol. 65, no. 3, pp. 1280-1288, 1999.

[149] C. M. Santegoeds, L. R. Damgaard, G. Hesselink et al., "Distribution of sulfate-reducing and methanogenic bacteria in anaerobic aggregates determined by microsensor and molecular analyses," Applied and Environmental Microbiology, vol. 65, no. 10, pp. 4618-4629, 1999.

[150] G. Gonzalez-Gil, P. N. L. Lens, A. Van Aelst, H. Van As, A. I. Versprille, and G. Lettinga, "Cluster structure of anaerobic aggregates of an expanded granular sludge bed reactor," Applied and Environmental Microbiology, vol. 67, no. 8, pp. 3683-3692, 2001.

[151] S. Rocheleau, C. W. Greer, J. R. Lawrence, C. Cantin, L. Laramée, and S. R. Guiot, "Differentiation of Methanosaeta concilii and Methanosarcina barkeri in anaerobic mesophilic granular sludge by fluorescent in situ hybridization and confocal scanning laser microscopy," Applied and Environmental Microbiology, vol. 65, no. 5, pp. 2222-2229, 1999.

[152] E. Díaz, R. Amils, and J. L. Sanz, "Molecular ecology of anaerobic granular sludge grown at different conditions," Water Science and Technology, vol. 48, no. 6, pp. 57-64, 2003.
[153] Y. Saiki, C. Iwabuchi, A. Katami, and Y. Kitagawa, "Microbial analyses by fluorescence in situ hybridization of well-settled granular sludge in brewery wastewater treatment plants," Journal of Bioscience and Bioengineering, vol. 93, no. 6, pp. 601-606, 2002.

[154] B. Calli, B. Mertoglu, N. Tas, B. Inanc, O. Yenigun, and I. Ozturk, "Investigation of variations in microbial diversity in anaerobic reactors treating landfill leachate," Water Science and Technology, vol. 48, no. 4, pp. 105-112, 2003.

[155] K. Roest, H. G. H. J. Heilig, H. Smidt, W. M. De Vos, A. J. M. Stams, and A. D. L. Akkermans, "Community analysis of a full-scale anaerobic bioreactor treating paper mill wastewater," Systematic and Applied Microbiology, vol. 28, no. 2, pp. 175-185, 2005.

[156] S. Rosenberger, R. Witzig, W. Manz, U. Szewzyk, and M. Kraume, "Operation of different membrane bioreactors: experimental results and physiological state of the micro-organisms," Water Science and Technology, vol. 41, no. 10-11, pp. 269-277, 2000.

[157] M. Wagner, M. Hornt, and H. Daims, "Fluorescence in situ hybridisation for the identification and characterisation of prokaryotes," Current Opinion in Microbiology, vol. 6, no. 3, pp. 302-309, 2003.

[158] L. M. Steinberg and J. M. Regan, "Response of lab-scale methanogenic reactors inoculated from different sources to organic loading rate shocks," Bioresource Technology, vol. 102, no. 19, pp. 8790-8798, 2011.

[159] R. C. van Leerdam, F. A. M. de Bok, M. Bonilla-Salinas et al., "Methanethiol degradation in anaerobic bioreactors at elevated $\mathrm{pH}(\geq 8)$ : reactor performance and microbial community analysis," Bioresource Technology, vol. 99, no. 18, pp. 8967-8973, 2008.

[160] Y.-Q. Tang, T. Matsui, S. Morimura, X.-L. Wu, and K. Kida, "Effect of temperature on microbial community of a glucosedegrading methanogenic consortium under hyperthermophilic chemostat cultivation," Journal of Bioscience and Bioengineering, vol. 106, no. 2, pp. 180-187, 2008.

[161] W. Xing, Y. Zhao, and J.-E. Zuo, "Microbial activity and community structure in a lake sediment used for psychrophilic anaerobic wastewater treatment," Journal of Applied Microbiology, vol. 109, no. 5, pp. 1829-1837, 2010.

[162] Z.-B. Yue, J. Wang, X.-M. Liu, and H.-Q. Yu, "Comparison of rumen microorganism and digester sludge dominated anaerobic digestion processes for aquatic plants," Renewable Energy, vol. 46, pp. 255-258, 2012.

[163] M. Alzate, R. Muñoz, F. Rogalla, F. Fdz-Polanco, and S. PérezElvira, "Biochemical methane potential of microalgae: influence of substrate to inoculum ratio, biomass concentration and pretreatment," Bioresource Technology, vol. 123, pp. 488-494, 2012.

[164] S. Sunarso, S. Johari, and I. N. Widiasa, "The effect of feed to inoculums ratio on biogas production rate from cattle manure using rumen fluid as inoculums," International Journal of Waste Resources, vol. 2, pp. 1-4, 2012.

[165] A. Boulanger, E. Pinet, M. Bouix, T. Bouchez, and A. A. Mansour, "Effect of inoculum to substrate ratio (I/S) on municipal solid waste anaerobic degradation kinetics and potential," Waste Management, vol. 32, no. 12, pp. 2258-2265, 2012. 